\title{
Studentesimposium in die Natuurwetenskappe 30 Oktober 2009, Universiteit van die Vrystaat 'n Seleksie van referaatopsommings
}

Reëlingskommitee: Mnr. R.W. Pretorius (Dept. Geografie, Universiteit van Suid-Afrika), Dr. E. Snyders (NECSA), Prof. H. Swart (Dept. Fisika, Universiteit van die Vrystaat) en Prof. W. Purcell (Dept. Chemie, Universiteit van die Vrystaat)

\section{'n Oorsig van verskillende tipes luminessensie en verskillende tipes fosfors: gebruike en karakterisering}

\author{
M.M. BigGS*, O.M. NTwaeaborwa \& H.C. Swart \\ Departement Fisika, Universiteit van die Vrystaat \\ *biggsm.sci@ufs.ac.za
}

Luminessensie word gedefinieer as die fenomeen wat die opwekking van 'n stof se elektroniese toestand deur eksterne energie en die vrystelling van die opwekkingsenergie in die vorm van lig behels. Wanneer bestraling deur 'n foton of elektron, hitte, 'n chemiese reaksie of meganiese krag op 'n stof toegepas word, veroorsaak dit dat 'n elektron in die valensband van die atoom na die geleidingsband opgewek word. Die elektron kombineer dan met 'n holte in die valensband, en die oortollige energie word in die vorm van 'n foton vrygestel.

Daar is verskillende tipes luminessensie. Die algemeenste vorme van luminessensie is fluoressensie en fosforessensie. In beide gevalle is die opwekkingsbron fotone. Fluoressensie kan gesien word in fluoresserende gloeilampe, minerale en neonligte. In die geval van fosforessensie word die lig oor 'n langer tydperk vrygestel. Verf en speelgoed wat in die donker gloei, is tipiese voorbeelde van fosforessensie. Wanneer 'n elektriese stroom deur ' $n$ materiaal gestuur word en 'n foton in die proses afgegee word, staan dit as elektroluminessensie bekend. Voorbeelde hiervan is sakrekenaarskerms en digitale horlosies. As chemiese energie in lewende organismes in ligenergie omgeskakel word, staan dit as bioluminessensie bekend. Vuurvliegies en glimwurms is van die bekendste voorbeelde. Katodeluminessensie is die opwekking van ligenergie deur middel van elektrone. Televisie- en rekenaarskerms is voorbeelde hiervan. Meganoluminessensie is luminessensie wat afkomstig is van enige meganiese aksie op 'n vaste stof. Chemiese verbindings wat uitmekaargeskeur word, is 'n voorbeeld hiervan.

Die woord "fosfor" is afgelei uit die Griekse woord vir ligdraer. 'n Fosfor is enige stof wat daartoe in staat is om energie te absorbeer en dit in die vorm van lig uit te straal. Daar is twee tipes fosfors. Die een is die tipiese gloei-in-die-donker-fosfor wat lig oor 'n lang periode uitstraal, en die ander tipe straal lig net uit terwyl daar 'n opwekkingsbron is. Sodra die bron verwyder word, hou die fosfor op om lig uit te straal. Die gloei-in-die-donker-fosfor word vir luminesserende verf, klere, huisnommers, aanwysings en speelgoed gebruik. Gebruike van die ander tipe fosfor sluit in fluoresserende lampe, vertooneenhede soos katodestraalbuise, plat panele en organiese LED's, biologiese etikettering en kankerbehandeling.

Suid-Afrikaanse Tydskrif vir Natuurwetenskap en Tegnologie, Jaargang 29 No. 3: September 2010 
Verskillende materiale kan as fosfors gebruik word. Die meeste fosfors wat vir lampe en vertooneenhede gebruik word, is sulfied- of oksiedfosfors. Dit sluit matriksmateriale soos $\mathrm{ZnS}$, $\mathrm{CaS}, \mathrm{SiO}_{2}, \mathrm{ZnO}$ en $\mathrm{Y}_{2} \mathrm{SiO}_{5}$ in. Hierdie matrikse word met oorgangsmetale soos $\mathrm{Mn}^{2+}$ en lantaniedes soos $\mathrm{Ce}^{3+}$ gedoteer om verskillende golflengtes uit te straal. Die gloei-in-die-donker-fosfors is gewoonlik aluminiumoksiede soos $\mathrm{SrAl}_{2} \mathrm{O}_{4}$ :Eu,Dy en $\mathrm{BaAl}_{2} \mathrm{O}_{4}$ :Eu,Dy.

Die struktuur en morfologie van die monsters is bepaal met behulp van onderskeidelik $\mathrm{x}$-straaldiffraksie (XRD) en 'n skandeerelektronmikroskoop (SEM). Absorpsiedata is gebruik om die bandgaping $\left(\mathrm{E}_{\mathrm{g}}\right)$ van die fosfors te bepaal. Fotonluminessensie- (FL-) data is versamel om die effek van fotonopwekking te bepaal, en katodeluminessensie- (KL-) data is in 'n ultrahoë vakuum verkry om die effek van elektronopwekking te bepaal.

\section{An overview of different types of luminescence and different types of phosphors: their uses and characterisation}

The different types of luminescence and some examples are discussed in detail. Fluorescent and phosphorescent phosphors are discussed and examples of these phosphors are given. Some examples of sulphide, oxide and long afterglow phosphors are given and their different properties are discussed. Different structure and morphology techniques are also discussed.

\section{'n GIS-ondersteunde benadering ter visualisering van stedelike groei}

\section{D.P. Cilliers}

Departement Geografie, Noordwes-Universiteit

dirk.cilliers@nwu.ac.za

Die Verenigde Nasies (VN) voorspel dat 61\% van die wêreld se bevolking (ongeveer 4.9 biljoen mense) teen 2030 in stedelike nedersettings gaan woon. Daar word verder aangedui dat die meeste van hierdie verstedeliking in ontwikkelende lande en meer spesifiek in Afrika gaan plaasvind. Dit kan heel waarskynlik daaraan toegeskryf word dat die meeste lande in Afrika hulle tans in 'n oorgangsfase bevind, aangesien hulle stelselmatig van oorheersend landelike samelewings in oorheersend stedelike samelewings verander. Stedelike groei is dus 'n realiteit en 'n verskynsel wat 'n groot bedreiging vir globale volhoubaarheid inhou.

Om volhoubare ontwikkeling te verseker en effektief vir hierdie groei voorsiening te maak, benodig beplanners en owerhede optimale besluitneming-ondersteuningstelsels om ruimtelike ontwikkelingsplanne en grondgebruikbeleide te formuleer en te implementeer. Hierdie ondersteuningstelsels moet omvattend genoeg wees om volhoubare ontwikkeling op 'n proaktiewe wyse aan te moedig.

Een wyse waarop beplanners en owerhede in hierdie komplekse, belangrike taak bygestaan kan word, is deur hulle te voorsien van stedelike-groei-scenario's wat hulle sal help om ruimtelike ontwikkeling-raamwerke (in Engels spatial development frameworks of SDF) en -beleide te ontwikkel. Hoewel baie navorsing internasionaal op die gebied van stedelike-groei-modellering gedoen is, is die onderwerp nog weinig in Suid-Afrika nagevors.

In hierdie studie word 'n multikriteriabenadering gebaseer op 'n geografiese inligtingstelsel (GIS) gevolg om grondgebruikkonflikte te analiseer en grondgebruikgeskiktheidsanalises uit te voer. Hierdie analises neem drie kompeterende grondgebruike (stedelik, landbou en bewaring)

Suid-Afrikaanse Tydskrif vir Natuurwetenskap en Tegnologie, Jaargang 29 No. 3: September 2010 
in ag in 'n poging om deur middel van superponering die mees geskikte grond vir elk te identifiseer en toe te eien. Die resultate van die analises is uiteindelik gebruik as basisdatastelle vir stedelikegroei-modellering met behulp van GIS. 'n Suksesvolle stedelike-groei-scenario is vir 2030 vir Potchefstroom in die Noordwes-provinsie ontwikkel. Die studie het getoon dat 'n taamlik eenvoudige en deursigtige benadering tot stedelike-groei-modellering met beskikbare data in Suid-Afrika moontlik is.

\title{
A GIS-based approach for visualising urban growth
}

This study employs a multiple-criteria approach to analyse land-use conflicts as well as land-use suitability via a GIS-based weighted overlay procedure. The results of the analysis are ultimately used as inputs for urban growth modelling. A successful urban growth scenario was achieved for the city of Potchefstroom, South Africa.

\section{Vereenvoudigde chemiese modellering van rodiumkatalisator - wen of verloor?}

\author{
M.M. Conradie \& J. Conradie* \\ Departement Chemie, Universiteit van die Vrystaat \\ *conradj@ufs.ac.za
}

Die oksidatiewe reaksie van die toevoeging van kovalente molekules (soos alkiel-haliede) by oorgangsmetale is 'n fundamentele proses in homogene katalise. 'n Bekende voorbeeld hiervan is die oksidatiewe toevoeging van metieljodied tot $c i s-\left[\mathrm{Rh}(\mathrm{CO})_{2} \mathrm{I}_{2}\right]$, die Monsanto-katalisator wat in die produksie van asynsuur gebruik word. Die metanolkarbonaliseringsproses van die oorspronklike Monsanto-katalisator is alreeds wyd ondersoek - beide eksperimenteel en teoreties. ${ }^{1}$ Daarenteen is dieselfde oksidatiewe reaksie van die byvoeging van metieljodied tot [ $\mathrm{Rh}(\mathrm{acac})$ $\left.\left(\mathrm{P}(\mathrm{OPh})_{3}\right)_{2}\right](\mathrm{Hacac}=$ asetielasetoon, $\mathrm{Ph}=$ feniel $)$ nog net eksperimenteel ondersoek. Sover ons kennis strek, bestaan daar geen teoretiese inligting oor die geometrie en meganisme van die oorgangstoestand van die reaksie $\left[\mathrm{Rh}(\mathrm{acac})\left(\mathrm{P}(\mathrm{OPh})_{3}\right)_{2}\right]+\mathrm{CH}_{3} \mathrm{I}$ nie. Hierdie teoretiese studie fokus op die reagense, oorgangstoestand en moontlike produkte van laasgenoemde reaksie. Aangesien die OPh-groep die molekule se aantal atome drasties vermeerder, is vereenvoudigde modelle ook ondersoek om rekenaarberekeningsure te bespaar.

Met behulp van die Amsterdam-digtheidsfunksieprogram (ADF 2007) is 'n kwantumberekeningschemiestudie van die meganisme van die oksidatiewe reaksie van die toevoeging van $\mathrm{CH}_{3} \mathrm{I}$ tot $\left[\mathrm{Rh}(\mathrm{acac})\left(\mathrm{P}(\mathrm{OR})_{3}\right)_{2}\right]\left(\mathrm{R}=\mathrm{Ph}, \mathrm{CH}_{3}, \mathrm{H}\right)$ in die oplosmiddel metanol uitgevoer. Die oksidatiewe toevoeging van metieljodied by $\left[\mathrm{Rh}(\mathrm{acac})\left(\mathrm{P}(\mathrm{OR})_{3}\right)_{2}\right]$ lei tot 'n oktahedriese alkielproduk $\left[\mathrm{Rh}(\mathrm{acac})\left(\mathrm{P}(\mathrm{OR})_{3}\right)_{2}\left(\mathrm{CH}_{3}\right)(\mathrm{I})\right]$. Vier moontlike oktahedriese alkielisomere is weens die verskillende oriëntasies van die groepe rondom die rodiumsenter moontlik. Trans-toevoeging lei tot een moontlike produk en cis-toevoeging lei tot drie moontlike produkte. Die stabielste produk (met die laagste energie) is geïdentifiseer en die oorgangstoestand bereken (fig 1). Die berekende resultate stem met die eksperimentele resultate ooreen. ${ }^{2}$ Die groot negatiewe waarde vir die aktiveringsentropie (-129 $\left.\mathrm{J} \mathrm{mol}^{-1} \mathrm{~K}^{-1}\right)$ vir die oksidatiewe toevoeging dui op 'n assosiatiewe meganisme wat 'n polêre oorgangstoestand voorstel. Die vereenvoudigde modelle het insiggewende inligting ten opsigte van die geometrie en meganisme opgelewer. Die akkuraatste aktiveringsparameters is egter met behulp van die volledige model verkry.

Suid-Afrikaanse Tydskrif vir Natuurwetenskap en Tegnologie, Jaargang 29 No. 3: September 2010 


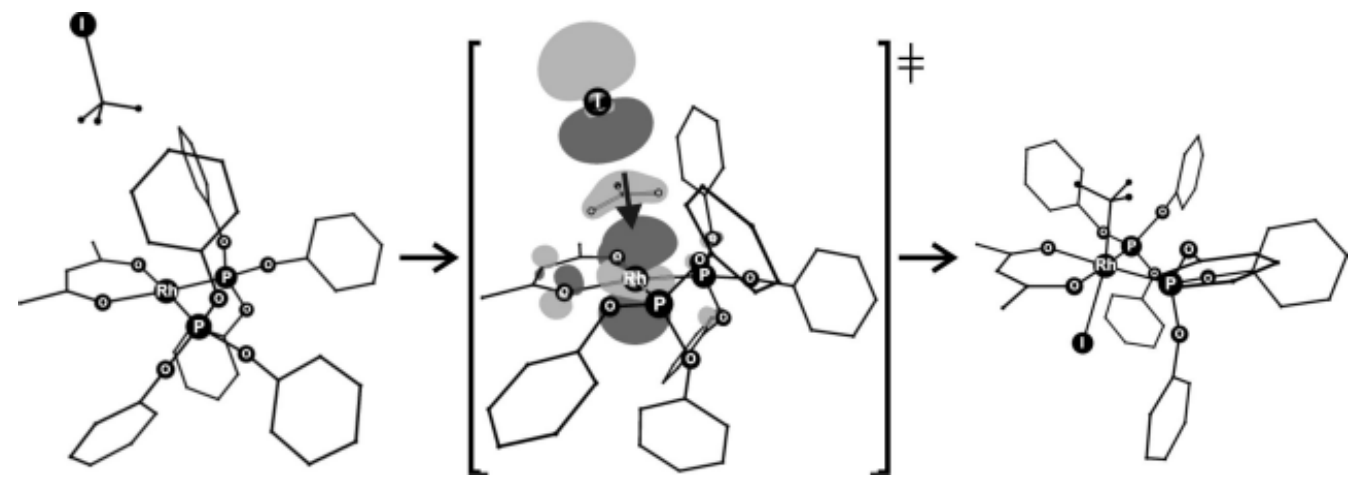

Figuur 1: Die oksidatiewe reaksie van die toevoeging van $\mathrm{CH}_{3} \mathrm{I}$ tot $\left[\mathrm{Rh}(\mathrm{acac})\left(\mathrm{P}(\mathrm{OPh})_{3}\right)_{2}\right]$ (links). Die oorgangstoestand (middel), waar die verplasingsvektor die bewegingsrigting aandui by die negatiewe frekwensie $\left(-270 \mathrm{~cm}^{-1}\right)$. Die hoogste gevulde molekulêre orbitale word ook op die middelste figuur aangedui - let op die gevulde $\mathrm{d}_{\mathrm{z} 2}$-orbitaal op die rodiumsenter. Die finale produk, $\left[\mathrm{Rh}(\mathrm{acac})\left(\mathrm{P}(\mathrm{OR})_{3}\right)_{2}\left(\mathrm{CH}_{3}\right)(\mathrm{I})\right]$ (regs) is die gevolg van cis-toevoeging van $\mathrm{CH}_{3}$ en $\mathrm{I}$ bo en onder die planêre vlak (gevorm deur die suurstof- en fosforatome). Al die waterstofatome, buiten dié by die metielgroep van $\mathrm{CH}_{3} \mathrm{I}$, is weggelaat om die figuur duideliker te maak

\title{
Verwysings
}

1. (a) Maitlis, P.M., Haynes, A., Sunley, G.J. \& Howard, M.J. (1996). J. Chem. Soc., Dalton Trans., 2187-2196. (b) Cavallo, L., Solà, M. (2001). J. Am. Chem. Soc., 123:12294-12302.

2. van Zyl, G.J., Lamprecht, G.J. \& Leipoldt, J.G. (1988). Inorg. Chim. Acta, 143: 223-227.

\section{Simplified DFT study of rhodium catalyst - win or lose?}

The reaction between $\mathrm{CH}_{3} \mathrm{I}$ and $\left[\mathrm{Rh}(\mathrm{acac})\left(\mathrm{P}(\mathrm{OR})_{3}\right)_{2}\right]\left(\mathrm{R}=\mathrm{Ph}, \mathrm{CH}_{3}, \mathrm{H}\right)$ has been studied theoretically. The study revealed that the reaction product forms through an associative mechanism which occurs via a polar transition state. Simplified models can be used to obtain geometrical and mechanistic information about molecules in the reaction.

\section{Korrelgroottes en tweelingstrukture in vervormde koper}

\author{
S. Cronje ${ }^{1 *}$, R.E. Kroon ${ }^{1}$, W.D. Roos $^{1}$ \& J.H. Neethling ${ }^{2}$ \\ ${ }^{1}$ Departement Fisika, Universiteit van die Vrystaat \\ ${ }^{2}$ Departement Fisika, Nelson Mandela Metropolitaanse Universiteit \\ *CronjéS.SCI@UFS.ac.za
}

Glip is die gewone vervormingsmeganisme van vlaksentriese kubiese materiale soos koper. Vervorming deur middel van vervormingstweelinge kan egter plaasvind in uiterste toestande, soos by lae temperature (vloeibare stikstof) of hoë $\left(1000 \mathrm{~s}^{-1}\right)$ vervormingstempo's.

Monsters is uit ' $n$ holladingplofkopkegel met 'n vonkerosiemasjien gesny. Hierdie tegniek is gebruik om te verseker dat die minimum verandering in die mikrostruktuur van die materiaal veroorsaak word. Elke monster is 30 minute lank by $300{ }^{\circ} \mathrm{C}$ en $500{ }^{\circ} \mathrm{C}$ uitgegloei, en sommige 
van die monsters is onverhit gelaat. Sommige van die monsters is na uitgloeiing met behulp van 'n splyt-Hopkinson-drukstaaf teen verskillende tempo's vervorm, terwyl die res onvervormd gelaat is. Twee vervormingstempo's is gebruik, naamlik $700 \mathrm{~s}^{-1}$ en $1550 \mathrm{~s}^{-1}$. Die monsters is gepoleer, geëts, en daarna met behulp van 'n aftaselektronmikroskoop, 'n atoomkragmikroskoop en 'n optiese mikroskoop ondersoek.

Die resultate het getoon dat die koper voor uitgloeiing 'n hoogs vervormde en verlengde korrelstruktuur het. Volgens die Heyn-metode is bevind dat die gemiddelde korrelgrootte na uitgloeiing by 300 ÚC en 500 ÚC onderskeidelik 5 ìm en 9 ìm was. Uitgloeitweelinge is ook in hierdie kopermonsters opgemerk. Die invloed van hierdie tweelinge op die gemete korrelgroottes word hier bespreek.

In 'n transmissie-elektronmikroskoop-ondersoek is die teenwoordigheid van tweelinge in beide die verhitte en vervormde kopermonsters opgemerk. Geen tweelinge is in die oorspronklike of die onverhitte maar vervormde monsters opgemerk nie. Die ordegroottes van hierdie tweelinge verskil van dié van tweelinge wat in die geëtste monsters waargeneem is. Hierdie tweelinge kan dus nie uitgloeitweelinge wees nie, aangesien hulle nie in die verhitte maar onvervormde monsters voorkom nie. Hulle word dus as vervormingstweelinge geïdentifiseer. Hierdie tweelingvervorming het by ' $n$ laer vervormingstempo plaasgevind as wat vooraf voorspel is.

\title{
Grain size and twin structures in deformed copper
}

Face-centered cubic metals, such as copper, deform plastically due to dislocation slip. Yet deformation twinning occurs if deformed at low temperatures or at high strain rates. This study shows that the conditions needed for deformation twinning to occur do not have to be as extreme as the literature suggests.

\section{Aluminium-(III-) triflaat as 'n katalisator vir die ring-oopmaak van epoksiede: sintese van piperasien-bevattende $\beta$-aminoalkohole}

\author{
A. Cullen \\ Departement Chemie, Universiteit van Johannesburg \\ adamc2006@gmail.com
}

Lewissure is as katalisators in ' $\mathrm{n}$ wye verskeidenheid organiese reaksies gebruik. ${ }^{1}$ Hierdie reaksies word gekenmerk deur unieke reaktiwiteit en selektiwiteit asook milde reaktiewe toestande. ${ }^{1}$ Voorbeelde van tradisionele Lewissure sluit in $\mathrm{AlCl}_{3}, \mathrm{BF}_{3}, \mathrm{TiCl}_{4}$ en $\mathrm{SnCl}_{4}$. Laasgenoemde sure behels egter die gebruik van stoïgiometriese hoeveelhede van die suur in watervrye toestande, met 'n klein moontlikheid vir die herwinning en hergebruik van die Lewissuur. Metaalriflate is onlangs deur Kobayashi en sy medewerkers gebruik om verskeie reaksies te kataliseer. Hulle het bevind dat die triflaattipe Lewissure minder sensitief is vir water en in substoïgiometriese hoeveelhede gebruik kan word. ${ }^{1}$

Aluminium- (III-) triflaat $\left(\mathrm{Al}(\mathrm{OTf})_{3}\right)$ is onlangs as 'n effektiewe katalisator vir die ringoopmak van epoksiede deur amiene gerapporteer. ${ }^{2}$ Hoë opbrengste met kort reaksietye was die norm. Piperasien-bevattende â-aminoalkohole (fig 1) is bekend vir hul biologiese aktiwiteit aangesien daar onlangs getoon is dat hulle as $\mathrm{Ca}^{2+}$-antagoniste en dopamienopname-inhibeerders funksioneer..$^{3-4}$ 


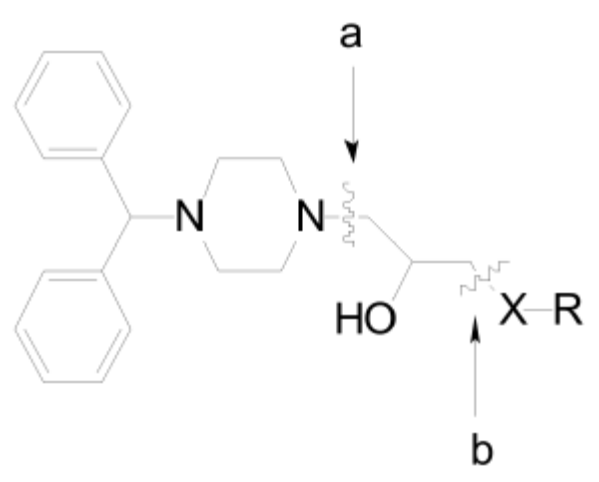

Figuur 1: Piperasien-bevattende $\beta$-aminoalkohol met bindingsdiskonneksies

In hierdie werk word twee verskillende benaderings tot die verlangde â-aminoalkohole bespreek (fig 1). Volgens die eerste benadering (fig 1, diskonneksie a), is die N-C-binding uit 'n vooraf gevormde epoksied en piperasienamien gevorm. Volgens die tweede benadering, (fig 1, diskonneksie $b$ ) is die C-X-binding uit 'n vooraf gevormde piperasien-bevattende epoksied en 'n H-X-R-molekuul gevorm, waar X swawel-, suurstof- of stikstofatome voorstel. In albei gevalle dien $\mathrm{Al}(\mathrm{OTf})_{3}$ as die Lewissuurkatalisator in die reaksie. Die gebruik van $\mathrm{Al}(\mathrm{OTf})_{3}$ vir die sintese van die stikstof-bevattende epoksiede, asook die voordeel van hierdie metode bo die tradisionele basisgekataliseerde reaksie, word ook bespreek. Die opskaal van die reaksies asook die herwinning en hergebruik van die $\mathrm{Al}(\mathrm{OTf})_{3}$-katalisator word beskryf.

\section{Verwysings}

1. Kobayashi, S., Sugiura, M. Kitagawa, H. \& Lam, W.W.L. (2002). Chem. Rev., 102:2227-2302.

2. Williams, D.B.G. \& Lawton, M. (2006). Tetrahedron Lett., 47:6557-6560.

3. Kimura, M., Masuda, T., Yamada, K., Mitani, M., Kubota, N., Kawakatsu, N., Kishii, K., Inazu, M., Kiuchi, Y., Oguchi, K. \& Namiki, T. (2003). Biorg. Med. Chem., 11:3953-3963.

4. Kimura, M., Masuda, T., Yamada, K., Mitani, M., Kubota, N., Kawakatsu, N., Kishii, K., Inazu, M., Kiuchi, Y., Oguchi, K.\& Namiki, T. (2004). Biorg. Med. Chem., 12:3069-3078.

\section{Aluminium(III) triflate as a catalyst for the ring-opening of epoxides: synthesis of piperazine- based $\beta$-amino alcohols}

Aluminium(III) triflate, a known catalyst for the aminolysis of epoxides, was found to be useful in the formation of $\beta$-amino alcohols bearing the piperazine motif. Many of these types of compounds show excellent biological activity. Details will be given of scale-up reactions and the recovery and recycling of the $\mathrm{Al}(\mathrm{OTf})_{3}$ catalyst. 


\title{
'n Naby infrarooi studie van die suidelike hoëmassa-ster- vormingsgebied RCW 34
}

\author{
*H.M .de Villiers ${ }^{\&}$ D.J. van der Walt \\ Departement Fisika, Noordwes-Universiteit \\ *lientjiedv@gmail.com
}

Die stervormingsgebied geassosieer met RCW 34 (G264.29+1.47) is gedurende die nagte van 18, 22 en 25 April 2005 met behulp van die 1.4m IRSF- (Infrared Survey Facility-) teleskoop van die SAAO op Sutherland waargeneem. RCW 34 is in die bande $J(1.25 \mu \mathrm{m}), H(1.64 \mu \mathrm{m})$ en $K_{s}(2.2 \mu \mathrm{m})$ waargeneem. Die kamera het 'n waarnemingsveld van 7.8' x 7.8' en 'n pikselskaal van 0.45 " gehad. Die beligtingstyd per beeld was $30 \mathrm{~s}$, en die totale beligtingstyd vir al drie nagte gesamentlik was drie uur. Die datareduksie is met behulp van die IRAF-sagtewarepakket gedoen, waarna die drie nagte se beelde mediaangekombineer is. Hierdie metode het my in staat gestel om 'n dieper beeld te genereer, sodat dowwer sterre opgespoor kon word. Die sterre is met behulp van die DAOPHOT-pakket in IRAF aan die beeld onttrek. Die PSF-pakket in IRAF is gebruik om fotometrie op hierdie sterre te doen vir die verkryging van instrumentele magnitudes. Die instrumentele magnitudes is met ooreenstemmende sterre uit die 2MASS-puntbronkatalogus gekalibreer, aangesien die opstapeling van beelde van verskeie nagte standaardsterkalibrasie verhinder het.

Die gekalibreerde sterre is gebruik om die verdelings in magnitude te ondersoek. Die dofste waargenome sterre was baie naby aan die teoretiese magnitudelimiet. Vervolgens is die kleure

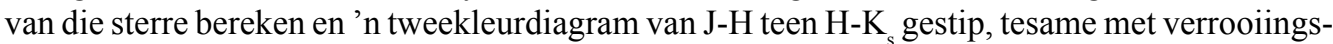
lyne soos bereken op grond van die verrooiingswette van Rieke et al. (1985) en die T Tauri lokus met sy verrooiingslyn. ${ }^{2}$

'n Merkwaardige opeenhoping van sterre tussen visuele uitdowings van 10 en 15 magnitudes, geleë tussen die hooftak- en T Tauri-verrooiingslyne, is waargeneem. Die koördinate van hierdie opeenhoping van sterre is op die beeld gestip. Daar is bevind dat hierdie sterre ' $n$ baie eweredige verspreiding oor die waarnemingsgebied toon, veral in gebiede rondom die stof. 'n Tweepuntkorrelasie-analise het die bestaan van 'n moontlike tweede stertros met 'n groter korrelasielengte aangetoon. ' $n$ Moontlike verklaring vir hierdie opeenhoping van skynbare $T$ Tauri-sterre is dat dit 'n tweede, ouer stertros op die agtergrond is wat alreeds effens uitgesprei het en 'n korrellasielengte groter as die dimensies van die beeldraam het. Verdere spektroskopiese analise is egter nodig om die aard van hierdie sterre te bevestig.

Die sterre wat in al drie kleurbande ooreenstem, is ook gebruik om 'n kleurmagnitudediagram te stip. 'n Gekombineerde isochroon van Harayama et al. (2008) is gebruik om die kleursnydingsmetode toe te pas. Aangesien daar nie 'n kontroleveld vir RCW 34 geneem is nie, is hierdie kleursnydingsmetode gebruik om alle sterre blouer as die isochroon te onttrek en 'n statistiese benadering vir die $K_{s}$-band-helderheidsfunksie van die kontroleveld te vorm. Hierdie $K_{s}$-bandhelderheidsfunksie is van die helderheidsfunksie vir die volledige stertros afgetrek, die resultaat is op 'n logaritmiese y-as gestip, en 'n magswet van 0.31 is verkry. Hierdie magswet stem ooreen met dit wat in die literatuur verkry is ten opsigte van stertrosse wat hoofsaaklik uit laemassasterre met 'n ouderdom van ongeveer 1 miljoen jaar bestaan, ${ }^{4}$ wat hierdie merkwaardige opeenhoping van $\mathrm{T}$ Tauri-sterre moontlik kan bevestig. 


\section{Verwysings}

1. Rieke, G. H.\& Lebofsky, M. J. (1985). Astrophysical Journal, 288:618.

2. Meyer, M. R., Calvet, N.\& Hillenbrand, L. A. (1997). Astronomical Journal, 114: 288.

3. Harayama, Y., Eisenhauer, F.\& Martins, F. (2008). Astrophysical Journal, 675: 1319.

4. Balog, Z., Kenyon, S. J.\& Lada, E. A., et al. (2004). Astronomical Journal, 128: 2942.

\section{A near infrared study of the southern high-mass star forming region RCW 34}

A near infrared photometric study attempted to classify the stellar population of RCW 34. Different graphical analyses suggested an unusual high population of T Tauri stars. Apparently two stellar populations from different epochs exist, projected on top of each other. The larger T Tauri cluster initially formed, followed by the formation of the high-mass star and its associated young stars. Follow-up spectroscopy is necessary to confirm these results.

\section{Sintese van 'n mikolmotief vir TB-diagnose}

\section{C.H.S. DRIVER}

Departement Chemie, Universiteit van Pretoria s23051991@tuks.co.za

Tuberkulose (TB) kom wêreldwyd maar veral in Afrika voor, en is die oorsaak van die meeste sterftes by pasiënte wat MIV positief is. ${ }^{1}$ TB kan genees word, maar voordat daar met behandeling begin kan word, moet daar 'n vinnige en akkurate diagnose wees.

Mikolsure wat in die beskermende waslaag van die selwand van Mycobacterium tuberculosis geleë is, is die oorsaak van TB. Dit word deur teenliggame erken en kan dus 'n roete vir TBserodiagnose voorsien.

Mikolsure bestaan uit twee hoofdele. Die eerste gedeelte is ' $n$ mikolmotief wat ooreenstem met dié van ander mikrobakterieë en uit 'n $\mathrm{C}_{24} \beta$-alkielketting en 'n â-hidroksigroep in 'n $R, R$ konfigurasie bestaan. ${ }^{2}$ Die tweede gedeelte is 'n meromikolaatketting met spesifieke funksionele groepe wat die mikolsure in verskillende subklasse klassifiseer. Hierdie subklasse staan as alfa-, keto- en metoksi-mikolsure bekend en is verantwoordelik vir verskillende funksies in die sel. Mikolsuursintese is van belang by die ondersoek van die struktuur-funksie-verwantskappe van die verskillende subklasse. Die bevindings kan dan gebruik word vir die ontwikkeling van nuwe TB-diagnosetegnieke soos biosensor-essaiëring. ${ }^{3}$

Die eerste stap in die bereiding van die mikolsuur is die sintese van die mikolmotief wat noodsaaklik is om die eienskappe van die mikolsuur en die relatiewe funksie in die sel te bepaal. Dit vorm die fokus van hierdie projek.

Die herkenning van die mikolmotief deur teenliggame word beïnvloed deur die teenwoordigheid van die twee stereogeniese sentra in die $\alpha$ - en $\beta$-posisies met die bewese $R, R$ konfigurasie. Enige sintetiese roete benodig dus effektiewe stereokontrole.

Die metodes wat voorheen vir die mikolmotiefsintese gebruik is, vorm die twee stereogeniese sentra in opeenvolgende reaksies. ${ }^{4,5}$ Die nuwe voorgestelde sintese wat die biosintetiese roete benader, fokus op die gelyktydige daarstelling van beide die á- en â-stereogeniese sentra deur 'n anti-aldolreaksie wat bemiddel word deur 'n chirale helper soos deur Kurosu et al. ${ }^{6}$ aangedui.

Die stereochemie van die aldolreaksie tussen ester $\mathbf{V}$ en aldehied $\mathbf{I V}$ word gedirigeer deur 'n norefedrien-afgeleide chirale helper om die diastereomeer III in 'n $R, R$-konfigurasie te gee.

Suid-Afrikaanse Tydskrif vir Natuurwetenskap en Tegnologie, Jaargang 29 No. 3: September 2010 
Die aldehied IV is deur middel van 'n Julia-reaksie tussen ' $\mathrm{C}_{3}$ - en 'n $\mathrm{C}_{8}$-diol gesintetiseer en bevat ' $n$ beskermde terminale hidroksigroep vir toekomstige binding aan die meromikolaatketting. Die ester III bevat 'n terminale dubbelbinding vir die verlenging van die á-alkielketting.

Met die daarstelling van verbinding III is die rol van die chirale helper uitgedien en kan dit dus deur middel van transesterifikasie en daaropvolgende herwinning verwyder word.

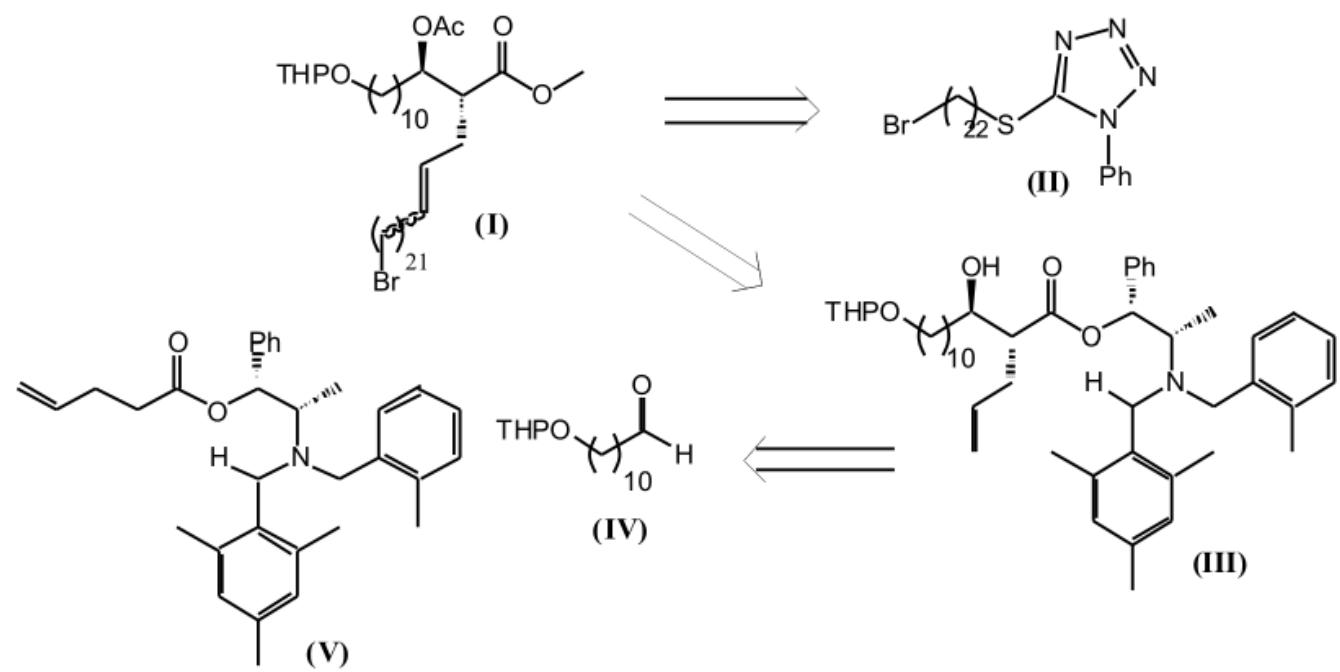

Figuur 1: Die gebromineerde alkielfragment II is vanaf ' $n C_{10^{-}}$en ' $n C_{12}$-diol gesintetiseer en is gebruik om produk I te sintetiseer en sodoende die mikolmotief te funksionaliseer.

Ter afsluiting, die mikolmotief is gesintetiseer volgens 'n nuwe anti-aldolmetode wat die vereiste stappe van sewe tot drie verkort en die funksionalisering van die mikolmotiefketting vir verdere ondersoeke van mikolsuur in TB-diagnose moontlik maak.

\section{Verwysings}

1. Harries, A., Maher, A. \& Graham, S. (2004). TB/HIV: a clinical manual, $2^{\text {nd }}$ edition, Geneva: WHO, 329.

2. Minnikin, D.E. \& Polgar, N. (1966). Chem. Commun., 648-649.

3. Thanyani, S.T., Roberts, V., Siko, D.G., Vrey, P.\& Verschoor, J.A. (2008). J. Immunol. Methods, 332:6172.

4. Al-Dulayymi, J., Baird, M.S.\& Roberts, E. (2005). Tetrahedron, 61:11939-11951.

5. Toschi, G.\& Baird, M.S. (2006). Tetrahedron, 62:3221-3227.

6. Kurosu, M. \& Lorca, M. (2001). J. Org. Chem., 66:1205-1209.

\section{Synthesis of a mycolic motif for the advancement of TB diagnostics}

Mycolic acids, located in the protective wax coat of the cell wall of Mycobacterium tuberculosis, the cause of tuberculosis (TB), have been recognised by antibodies and could be used in TB serodiagnosis. A novel method for stereoselective synthesis of the mycolic motif via an asymmetric anti-aldol reaction is reported 


\title{
'n Kritiese evaluasie van die plasing van die Ingula-pomp- opgaarskema
}

\author{
A. Du Plessis \\ Departement Geografie, Universiteit van Johannesburg \\ anjadup1@gmail.com
}

Die Ingula-pompopgaarskema (POS), wat tevore as Braamhoek bekend gestaan het, is in die Drakensbergreeks op die grens tussen die Vrystaat en KwaZulu-Natal geleë. Die ontwikkeling van die Ingula-POS het met groot omstredenheid gepaardgegaan, hoofsaaklik as gevolg van die negatiewe omgewingsimpak asook ongerymdhede rakende die omgewingsimpakstudieverslag. Die skema beoog om 1332 megawatt energie vir spitsaanvraagperiodes met 'n doeltreffendheid van $76 \%$ te produseer. Daar word ook beoog om 80 direkte werksgeleenthede in die bedryf van die skema en 20 voltydse bewaringswerksgeleenthede te skep.

Die ontwikkeling gaan tot gevolg hê dat 3\% van die 106 ha-Bedford/Chatsworth-vleiland, $10810000 \mathrm{~m}^{3}$ veen asook die Bedfordspruitwaterval en -grot oorstroom word. Hierdie omgewing is die tuiste van die bedreigde witvlerkvleikuiken en ander bedreigde voëlspesies. Die IngulaPOS sal dus 'n negatiewe impak op die bedreigde witvlerkvleikuiken hê en tot die verlies van 'n potensiële varswaterbron aanleiding gee. Dit kan ook veroorsaak dat die vleiland en veengebiede in bronne van koolstofdioksied omskep word.

In hierdie studie word daar beoog om 'n volledige historiese tydlyn saam te stel en om die gekose ligging krities te evalueer. Die kritiese evaluasie van die gekose ligging sal bestaan uit 'n evaluering van die omgewings-, sosiale en ekonomiese impak sowel as die identifisering en evaluering van relevante nasionale en internasionale omgewingswetgewing.

Die geskiedenis van die Ingula-POS getuig van vele probleme, selfs voor die aanvang van konstruksie. Al die relevante nasionale en internasionale omgewingswetgewing is egter wel in ag geneem, asook al die regulasies wat ingevolge die Wet op Omgewingsbewaring voorgeskryf is. Hierdie studie het egter bevind dat die Ingula-POS strydig met bepaalde internasionale konvensies mag wees. Selfs al is die Bedford/Chatsworth-vleiland nie 'n amptelike Ramsargebied nie, behoort ander internasionale omgewingswetgewing steeds in ag geneem te word. Die Konvensie op Biologiese Diversiteit moes byvoorbeeld in aanmerking geneem gewees het weens die nasionale betekenis van die gebied ten opsigte van biologiese diversiteit. Die moontlikheid bestaan dus dat die ontwikkeling strydig kan wees met dié Konvensie asook met die Bonnkonvensie, as gevolg van die gepaardgaande negatiewe impak op bedreigde voëlspesies.

Wat kommerwekkend is, is dat die omgewingskonsultant wat aangestel is, Poltech, deur 'n voormalige Eskom-werknemer gestig is. Die hoofomgewingskonsultant is ook 'n voormalige Eskom-werknemer. Die onafhanklikheid van die omgewingskonsultasie word dus deur verskeie partye bevraagteken. Voorts was die omgewingsimpakevaluering nie op standaard nie, en is verskeie teenstrydighede in die voltooide omgewingsimpakverslag geïdentifiseer.

Alhoewel daar volgens hierdie studie ongerymdhede plaasgevind het, is die periode van besware en kritiek aangaande die ontwikkeling reeds verby. Oplossings moet dus ontwikkel en uitgevoer word om te verseker dat hierdie foute sover moontlik reggestel word en dat Ingula wêreldwyd bekendheid as volhoubare bewaringsgebied sal verwerf. 


\title{
A critical evaluation of the location of the Inguela Pump Storage Scheme
}

The Ingula Pump Storage Scheme has been fraught with controversy as a result of the associated serious environmental impact, as well as certain identified flaws in the completed Environmental Impact Report. A historical time line has been constructed and the location has been critically evaluated in terms of the environmental, social and economic impact thereof.

\section{Fischer-metaalkarbene as alkeenmetatesekatalisatore}

\author{
J.I. du Toit*, C.G.C.E. van SitTert \& H.C.M. Vosloo \\ Chemiese Hulpbronveredeling, Noordwes-Universiteit \\ *12317624@nwu.ac.za
}

Alkeenmetatese is die uitruiling van dele van twee alkeenverbindings deur die breking en herrangskikking van die koolstof-koolstofdubbelbindings. ${ }^{1}$ Die uitruiling vind normaalweg in die teenwoordigheid van 'n katalisator plaas. Herbert S. Eleuterio het alkeenmetatese vir die eerste keer in 1956 waargeneem. ${ }^{1}$ Hy het 'n propeen-eteenko-polimeer verkry vanaf propeengas wat oor 'n molibdeen-aluminakatalisator gevloei het. 'n Analise het getoon dat die voergas 'n mengsel van propeen, eteen en 1-buteen bevat. Hierdie reaksie is deur Calderon alkeenmetatese (alkene metathesis) genoem. ${ }^{1}$

In 1970 het Herisson en Chauvin 'n nie-paarsgewyse meganisme wat langs 'n metallasiklobutaantussenverbinding loop vir alkeenmetatese voorgestel. ${ }^{1}$ Chauvin se meganisme het voorgestel dat metaalkarbeenkomplekse as katalisatore vir die alkeenmetatesereaksie kan optree. Die enigste metaalkarbeenkomplekse wat toe bekend was, is deur die Fischer-groep berei. ${ }^{2}$ Veral $\mathrm{Katz}^{3}$ en $\mathrm{Casey}^{4}$ het baie navorsing oor die gebruik van die Fischer-karbene in alkeenmetatese gedoen.

In 1974 het Casey en Burkhardt vir die eerste keer getoon dat die metaalkarbeen (difenielkarbeen)pentakarbonielwolfram met isobuteen reageer om as hoofproduk ' $n$ nuwe alkeen, 1,1-difenieleteen, te vorm. ${ }^{1}$ Verder het Katz et al. ${ }^{5}$ in 1976 getoon dat dieselfde isoleerbare metaalkarbeenkompleks die metatese van onsimmetriese alkene inisieer.

Fischer-metaalkarbene, wat lae oksidasietoestandkarbene is, het 'n lae metatese-aktiwiteit. Volgens Casey se meganisme ('n voorstel gebaseer op Chauvin se meganisme) word 'n siklopropaan as neweproduk saam met die metateseprodukte gevorm. ${ }^{6}$ Casey stel voor dat die siklopropaanproduk óf direk óf deur reduktiewe eliminasie van die metallasiklobutaantussenverbinding gevorm word. 'n Fischer-tipe karbeen is 'n singletkarbeen wat welbekend is weens die vinnige en stereospesifieke addisie aan alkene om siklopropane te vorm.

Chauvin se meganisme kan 'n assosiatiewe of dissosiatiewe roete volg. In die assosiatiewe meganisme vorm die alkeen-katalisatorkompleks sonder die dissosiasie van 'n ligand van die katalisator. In die dissosiatiewe meganisme moet een van die ligande eers dissosieer om plek te maak vir die alkeen om te koördineer. Vir die metateseprodukte van die Fischermetaalkarbeengekataliseerde reaksie na aanleiding van Chauvin se meganisme is die vraag dan of die meganisme assosiatief of dissosiatief verloop. Op grond van eksperimentele getuienis stel Casey $^{6}$ in 'n latere artikel voor dat die reaksie slegs volgens die dissosiatiewe meganisme verloop.

In hierdie studie is ' $n$ modelleringsondersoek na die meganisme en produkte van die alkeenmetatesereaksie wat deur Fischer-tipe metaalkarbene gekataliseer word, gedoen. Uit die

Suid-Afrikaanse Tydskrif vir Natuurwetenskap en Tegnologie, Jaargang 29 No. 3: September 2010 
modelleringsresultate is potensiële-energie-oppervlak- (potential energy surface - PES) diagramme saamgestel, wat toon dat die meganisme wel volgens die dissosiatiewe meganisme verloop. Hierdie resultate bevestig $\mathrm{Casey}^{6}$ se voorstel dat die reaksie volgens die dissosiatiewe meganisme verloop.

Die modelleringsresultate bevestig ook $\mathrm{Casey}^{6}$ se eksperimentele resultate, wat getoon het dat siklopropaan die hoofproduk van die metatesereaksie is. Die modelleringsresultate steun ook die grensorbitaalteorie dat die aanvalsposisie eerder op die karbeenkoolstof is, wat verklaar waarom dit eerder siklopropaan is wat vorm.

Hierdie studie bied dus 'n verklaring vir die lae metatese-aktiwiteit van Fischer-tipe metaalkarbene. Alhoewel Fischer-metaalkarbene die begin van hierdie tipe homogene alkeenmetatesekatalisatore was, het die Grubbs- ${ }^{7}$ en Schrock-tipe ${ }^{8}$ metaalkarbene wat later in die 1990 s ontdek is, 'n groot invloed op die sintetiese toekoms van die alkeenmetatesereaksie uitgeoefen. Diepere insig in die meganistiese werking van metaalkarbene is egter noodsaaklik om meer effektiewe katalisatore te ontwikkel.

\title{
Verwysings
}

1. Ivin, K.J. (1983). Olefin metathesis, London: Academic Press Inc.

2. Grubbs, R.H. (2003). Handbook of metathesis, Vol 1, Weinheim: WILEY-VCH.

3. Katz, T.J.\& Acton, N. (1976). Tetrahedron Lett., 4251 en verwysings daarin.

4. Casey, C.P., Polichnowski, S.W., Shusterman, A.J. \& Jones, C.R. (1979). J. Am. Chem.Soc., 101:7282 en verwysings daarin.

5. Katz, T.J., McGinnis, J.\& Hurwitz, S. (1976). J. Am. Chem. Soc., 98:605.

6. Casey, C.P., Albin, L.D.\& Burkhardt, T.J. (1977). J. Am. Chem. Soc., 99:2533.

7. Nguyen, S.T., Johnson, L.K. \& Grubbs, R.H. (1992). J. Am. Chem. Soc., 114:3974.

\section{Fischer metal carbenes as alkene metathesis catalysts}

Alkene metathesis can be catalysed by metal carbenes. Fischer metal carbenes were the first carbene catalysts, but they showed only low activity. Cyclopropane forms as the major product and not the metathesis products. This study is a modelling enquiry into the mechanism of Fischer metal carbenes as catalysts for alkene metathesis.

\section{Monte Carlo-simulasie en AES-karakterisering van fasevorming in Pt-Al- dun lae}

\author{
$1 *$ R.A. Harris, ${ }^{2}$ E. van der Lingen, ${ }^{3}$ D.F. Paul, ${ }^{1}$ H.C. Swart $\& ~{ }^{1}$ J.J. Terblans \\ ${ }^{1}$ Departement Fisika, Universiteit van die Vrystaat \\ ${ }^{2}$ Mintek, Johannesburg \\ ${ }^{3}$ Physical Electronics Labs, VSA \\ *harrisra.sci@ufs.ac.za
}

Konvensionele grootmaat- en dunlaagdiffusie is al baie jare lank 'n populêre studie-onderwerp. Een van die tegniese probleme wat ondersoek word, is die samevoeging van twee ongelyksoortige materiale. Een sodanige sisteem wat intensief bestudeer word, is die platinum-aluminiumdunlaagsisteem met sy vele industriële toepassings. Platinumgebaseerde allooie word vir hoëtemperatuurtoepassings ontwikkel omdat dit potensieel uiters goeie korrosie- en oksidasiweerstand bied. Om die effektiwiteit van moderne gasturbine-enjins te verbeter, moet die 
werkstemperatuur van verskeie dele van die enjin verhoog word. Hierdie verhoging in werkstemperature veroorsaak egter oksidasieprobleme. Om die probleem van oksidasie by hoë temperature te oorkom, word verskeie oppervlakbeskermingslae ontwikkel en bestudeer. Pt/Alallooie, wat op die $\mathrm{Pt}_{3} \mathrm{Al}$-verbinding gebaseer is, het die potensiaal om by ultrahoë temperature goeie korrosie- en oksidasieweerstand te bied. Daarom word diffusiestudies daarop uitgevoer om die mobiliteit van die verskillende elemente te ondersoek. ' $\mathrm{n} \mathrm{Pt} / \mathrm{Rh} / \mathrm{Al}$-allooi wat by ' $\mathrm{n}$ temperatuur van $550^{\circ} \mathrm{C}$ uitgegloei word, word deur middel van skandeer-Auger-mikroskopie (SAM) ondersoek. Die waargenome diepteprofiel en skandeerelektronmikroskoop- (SEM-)beelde asook die elementkaarte word dan met resultate van 'n Monte Carlo-model vergelyk. Hierdie Monte Carlo-model is ontwikkel om die mikrostruktuur van 'n binêre allooi te voorspel. Die eksperimentele resultate en die voorspelde mikrostruktuur vergelyk goed.

\title{
Monte Carlo simulation and AES characterisation of phase forming in Pt-Al thin films
}

A chemical potential Monte Carlo model is developed and employed to predict the microstructure of a $\mathrm{Pt} / \mathrm{Rh} / \mathrm{Al}$ thin-film system at an annealing temperature of $550{ }^{\circ} \mathrm{C}$. The predicted results are compared to experimentally measured AES elemental maps and SEM images. A good correlation between the theoretical model and the experimentally measured results were found.

\section{Chemiese omskakeling van plantmateriaal na biobrandstowwe in nie-klassieke toestande}

\section{Y. NorTJE}

\author{
Departement Fisiese en Chemiese Wetenskappe, Noordwes-Universiteit
}

20067224@nwu.ac.za

Die gebruik van fossielbrandstof het om verskeie redes problematies geword. Die redes hiervoor is die afname in beskikbaarheid, die toename in aanvraag, die onbestendige ru-olieprys, en besorgdheid oor die uitwerking van uitlaatgasse op die omgewing. Die vervaardiging van alternatiewe brandstowwe het dus noodsaaklik geword. Plantmateriaal is waarskynlik 'n volhoubare bron van organiese koolstof waaruit biobrandstowwe vervaardig kan word. Die saad van die dieselboom (Jatropha curcas) word byvoorbeeld gebruik om biodiesel te vervaardig, ${ }^{1}$ en sojaboonolie en metanol word vermeng om een van die eenvoudigste vorme van biodiesel te lewer. ${ }^{2}$

Die klem val in hierdie ondersoek op die aanwending van nie-klassieke metodes, waaronder superkritiekefluïedekstraksie (SFE), mikrogolfgesteunde superverhitting (MAS) ${ }^{3}$ en ultrasoniese aktivering, om plantkomponente vir uiteindelike omskakeling na biobrandstowwe te ekstraheer, en op die analise van ekstrakte en biomassa-omsettings deur middel van twee-dimensionele gaschromatografie en vlugtydmassaspektro-meteriese deteksie (GCxGC/TOF-MS) ten einde die resultate met kommersiële biodieselmonsters en met wetenskaplike (SABS-)standaarde te vergelyk.

In hierdie voordrag word die eksperimentele resultate wat tot dusver met saad van Jatropha curcas verkry is, bespreek. Twee verskillende ekstraksiemodusse met superkritieke koolstofdioksied $\left(\mathrm{sc}-\mathrm{CO}_{2}\right)$ is gebruik om die olie-inhoud van die saad (dinamiese modus) en die oplosbaarheid van die olie in die fluïed (statiese modus) in vooraf gekose toestande te bepaal. Die oplosbaarheid van die olie in sc- $\mathrm{CO}_{2}$ word met dié van enkele ander plantaardige olies (sonneblom, kanola, soja) vergelyk. 
Die meer as 200 komponente wat in 'n tipiese ekstrak deur middel van twee-dimensionele gaschromatografie geïdentifiseer is, word met gepubliseerde gegewens ${ }^{4}$ oor die samestelling van Jatropha curcas-olie en met die samestelling van 'n kommersiële dieselmonster vergelyk. ${ }^{5}$ Dit het aanvanklik gelyk asof hoofsaaklik koolwaterstowwe, karboksielsure, alkohole en aldehiede geëkstraheer is, en dat die meeste vetsure behalwe vir oliënsuur ontbreek het. Dit is juis hierdie vetsure wat omskep word in die vetsuurmetielesters (FAME) waaruit biodiesel bestaan. Jatropha curcas-olie is veronderstel om ongeveer $14 \%$ vrye vetsure (FFA) te bevat, wat die vereiste limiet van $1 \%$ vrye vetsuurinhoud vir die omskakeling na biodiesel met bevredigende eienskappe deur transesterifikasie met 'n alkaliese katalisator ver oortref. Die geslaagde omskakeling na metielesters het egter bevestig dat die vetsure inderdaad geëkstraheer is, maar verskuil was as glisiriede wat nog in vetsure en gliserol afgebreek moes word. Dit kon later met behulp van 'n kolom spesifiek vir gliseriedanalise bevestig word.

Die projek maak voorsiening vir uitbreiding na die aanwending van superverhitte, subkritieke en superkritieke water $\left(\mathrm{sc}-\mathrm{H}_{2} \mathrm{O}\right)$, en na ander biomatryse as dieselboomsaad. Suurstofbevattende organiese molekule ondergaan reaksies in bogenoemde media aangesien die minder polêre oplosmiddel $\left(\mathrm{H}_{2} \mathrm{O}\right)$, die nie-polêre oksideermiddel $\left(\mathrm{O}_{2}\right)$ en die nie-polêre organiese verbinding (oksigenaat) in toenemende mate onderling versoenbaar raak namate die temperatuur toeneem. ${ }^{6}$ Hout is byvoorbeeld ' $n$ hernubare bron wat oor suurstofbevattende molekule beskik. Dit behoort moontlik te wees om hout met superverhitte water te klief en die vloeibare produkte na 'n biobrandstof op te gradeer. Die resultate kan vergelyk word met dié wat met sub- en superkritieke water verkry is, ten einde die geskikste metode vir biomassa-omsetting te identifiseer.

\section{Verwysings}

1. Palgrave, K.C. (2002). Trees of Southern Africa, Cape Town: Struik, 512.

2. Dunn, R.O. (2005). Effect of antioxidants on the oxidative stability of methyl soyate (biodiesel). Fuel Processing Technology, 86(10):1071-1085.

3. Kingston, H.M. \& Haswell, S.J. (1997). Microwave-Enhanced Chemistry. Fundamentals, Sample Preparation and Applications. Washington: American Chemical Society, 572.

4. Tiwari, A.K., Kumar, A. \& Raheman, H. (2007). Biodiesel production from Jatropha curcas oil with high free fatty acids: An optimized process. Biomass and Bioenergy, 31:569-575.

5. Pramanik, K. (2003). Properties and use of Jatropha curcas oil and diesel fuel blends in compression engines. Renewable Energy, 28(2):239-248.

\section{Chemical conversion of plant material to biofuels under non-classical conditions}

The use of fossil fuels has become problematic and necessitates production of biofuels. In this investigation non-classical methods are employed to extract oil from Jatropha curcas seed for subsequent conversion to fatty acid methyl esters (FAME) contained within biodiesel. Analysis of extracts and of biomass conversions is performed by GCxGC/TOF-MS. 


\title{
Die Pd-verwering van SiC
}

\author{
*E.J. Olivier \& J.H. Neethling
}

Departement Fisika, Nelson Mandela Metropolitaanse Universiteit

*s202311570@nmmu.ac.za

$\mathrm{SiC}$ is 'n halfgeleidende keramiek met 'n wye bandgaping wat onder andere as hulslagie in TRISO-bedekte kernkragbrandstofdeeltjies gebruik word, omrede $\mathrm{SiC}$ uitstekende termiese en meganiese stabiliteit tesame met ' $\mathrm{n}$ chemiese onreaktiwiteit het. SiC is weliswaar by hoë temperature $\left(>800^{\circ} \mathrm{C}\right)$ vatbaar vir chemiese aanval deur $\mathrm{Pd}$, wat lei tot die verwering van $\mathrm{SiC}$ omdat 'n palladiumsilisied vorm deur die vervanging van $\mathrm{C}$ - 'n proses wat die strukturele integriteit van $\mathrm{SiC}$ benadeel. Boonop is palladium een van die hoofsplytingsprodukte wat tydens gebruik in die partikel vorm. 'n Belangrike vraag is dus wat die uitwerking van palladiumverwering na langdurige gebruik op die strukturele integriteit van die SiC-lagie in die brandstofdeeltjie is. Hierdie studie gee terugvoering oor 'n ondersoek van Pd-verwering in $\mathrm{SiC}$ met behulp van ' $\mathrm{n}$ transmissie-elektronmikroskoop (TEM), 'n skanderingselektronmikroskoop (SEM) en nanohardheidstoetsing. Pd-SiC-diffusiekoppels is vervaardig van CVD 6H, 3C en polikristallyne $3 \mathrm{C} \mathrm{SiC}$ en is daarna 24 uur lank by $1000^{\circ} \mathrm{C}$ hitte behandel. Poeiereksperimente van $\mathrm{Pd}-\mathrm{en} \mathrm{Pd} /$ Si-mengsels in kontak met twee tipes 3C-polikristallyne $\mathrm{SiC}$ is ook ondersoek na hittebehandeling.

TEM-resultate vir die enkelkristal $\mathrm{SiC}$ het duidelik getoon dat $\mathrm{Pd}$ met $\mathrm{SiC}$ reageer om 'n palladiumsilisied te vorm deur die verplasing van C. Die palladiumsilisiedstruktuur wat in die meeste gevalle gevind is, was dié van $\mathrm{Pd}_{2} \mathrm{Si}$. SEM- en TEM-resultate van die polikristallyne $\mathrm{SiC}$ het die verwering van $\mathrm{SiC}$ deur Pd getoon, asook die infiltrasie van Pd langs korrelgrense. Die resultate toon dat die reaksie tydens die eerste verweringsfase hoofsaaklik teen korrelgrense plaasvind. Verdere verwering van die $\mathrm{SiC}$ het ' $\mathrm{n}$ totale vervanging van $\mathrm{C}$ getoon en gelei tot die vorming van grafiet saam met palladiumsilisied. Nanohardheidsmetings het 'n drastiese afname getoon in die gemete hardheid van areas waar verwering plaasgevind het, vergeleke met ongeaffekteerde areas. Polikristallyne SiC wat met 'n Pd/Si-mengsel gereageer het, het na 24 uur by $1000^{\circ} \mathrm{C}$ langs korrelgrense ' $\mathrm{n}$ infiltrasie van palladium tot op 'n afstand van 15 ìm getoon.

\section{Verwysings}

1. Roy, S., Basu, S., Jacob, C.\& Tyagi, A.K. (2002). Applied Surface Science, 202:73.

2. Minato, K., Fukuda, K., Ishikawa, A. \& Mita, N. (1997). Journal of Nuclear Materials, 246:215.

\section{Pd corrosion of $\mathrm{SiC}$}

An investigation into the corrosion of $\mathrm{SiC}$ by $\mathrm{Pd}$ at high temperatures $\left(>800^{\circ} \mathrm{C}\right)$ was conducted. It was found that $\mathrm{Pd}$ corrodes $\mathrm{SiC}$ to form a palladium silicide through the replacement of $\mathrm{C}$. Results on polycrystalline $\mathrm{SiC}$ indicated a preferential corrosion along grain boundaries. Nanoindentation analyses found a severe degradation of the $\mathrm{SiC}$ mechanical properties. 


\title{
'n [2,3]-Wittig-herrangskikkingsbenadering tot die sintese van die fumonisien-ruggraat
}

\author{
*C. Slabbert \& R. VleggaAR \\ Departement Chemie, Universiteit van Pretoria \\ *s20049082@tuks.co.za
}

Fumonisien $B_{1}(\mathbf{1})$ is 'n lid van 'n familie van struktuurverwante mikotoksiene wat deur SuidAfrikaanse wetenskaplikes vanuit kulture van Fusarium moniliforme (stam MRC 287) geïsoleer en chemies gekarakteriseer is. Hierdie sekondêre metaboliete is algemene kontaminante van mielies oral ter wêreld.

Fumonisien $\mathrm{B}_{1}$ is struktuurverwant aan sfingoïedbasisse en belemmer gevolglik sfingolipiedbiosintese. Sfingolipiede is teenwoordig in alle eukariotiese selle en dien as strukturele molekules en reguleerders in verskeie selfunksies. Biologiese manifestasies van sfingolipiedinhibisie sluit van die volgende toestande in: slukdermkanker in die mens, neuraalbuisdefekte in babas en leukoensefalomasie in perde.

Alhoewel fumonisien $\mathrm{B}_{1}$ alreeds gesintetiseer is, duur die soeke na 'n korter, beter sintetiese roete steeds voort, om struktuuraktiwiteitstudies op hierdie mikotoksien te vergemaklik.

Fumonisien $B_{1}$ is 'n polêre di-ester met 'n poligehidroksileerde $C_{20}$-koolwaterstofruggraat (1). Die fumonisienruggraat bevat 8 stereogeniese sentra. Die stereoselektiewe daarstelling van die stereogeniese sentra in aanvaarbare optiese suiwerheid is een van die aspekte wat die sintese van die molekule uitdagend maak.

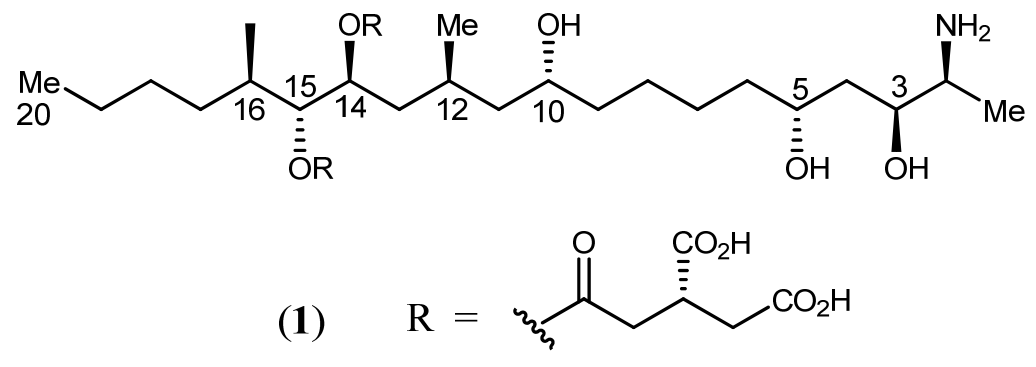

Figuur 1: Fumonisien $B_{1}$

Retrosintetiese analise van die $\mathrm{C}_{20}$-ruggraat dui op ontkoppeling van die $\mathrm{C}(12)$-C(13)-binding en lewer $(3 S, 4 R, 5 R)$-3,4-di(bensieloksi)-5-metielnonaan-1-ol (2) as chirale bousteen in die sintetiese roete wat lei tot die sintese van (1). Die sintese van hierdie intermediêr is dan ook die uiteindelike doel van hierdie projek. 


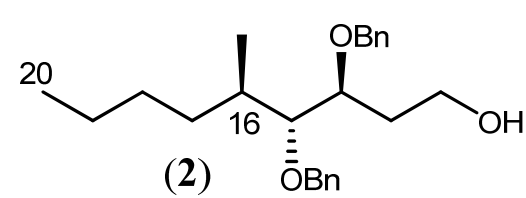

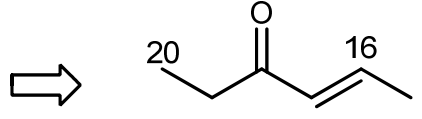

(3)

Figuur 2: Retrosintetiese opsomming van (3S,4R,5R)-3,4-di(bensieloksi)-5-metielnonaan-1-ol

Die retrosintetiese analise van (2) dui stapsgewys 'n eenvoudiger teikenmolekuul in die sintetiese rigting aan. Die analise het uiteindelik na trans-4-hekseen-3-oon (3) as uitgangstof gelei. 'n Uiteenlopende versameling chemiese reaksies is gebruik om die hantering en omskakeling van funksionele groepe wat tot die teikenproduk (2) lei, te verwesenlik. Sleutelreaksies wat in hierdie spesifieke sintetiese reeks gebruik is, sluit in: 1) ensimatiese kinetiese resolusie van 'n sekondêre alkohol met varkpankreaslipase, 2) 'n [2,3]-Wittig-herrangskikkingsreaksie, 3) hidroksimetilering en 4) Sharpless- asimmetriese epoksidasie.

Struktuurontledingstegnieke sluit die gebruik van ${ }^{1} \mathrm{H},{ }^{13} \mathrm{C}$ en verskeie tweedimensionele KMR-eksperimente in. Enantiomeriese oormaat is bepaal deur die ${ }^{19} \mathrm{~F}$ KMR-spektrum van die Mosher-esterderivate te analiseer.

\title{
A [2,3]-Wittig rearrangement approach towards the synthesis of the backbone of the fumonisins
}

Fumonisin $\mathrm{B}_{1}$ is a mycotoxin and a common contaminant of maize throughout the world. Synthetic studies towards the synthesis of the $\mathrm{C}_{20}$ backbone of fumonisin $\mathrm{B}_{1}$ form the platform of this study. $(3 S, 4 R, 5 R)-3,4-\mathrm{Di}$ (benzyloxy)-5-methylnonan-1-ol has been identified as a chiral building block towards the $\mathrm{C}_{20}$ backbone and key reactions towards its synthesis from trans-4-hexene-3-one will be discussed.

\section{Litostratigrafiese korrelasie van ysterryke sedimentêre gesteentes in die argaïese Witwatersrand-Mozaanopeenvolging: Implikasies vir vroeë afsettingsomgewings op aarde}

\author{
A.J.B. SMith ${ }^{1 *}$, N.J. Beukes ${ }^{1} \&$ J. Gutzmer ${ }^{2}$ \\ ${ }^{1}$ Departement Geologie, Universiteit van Johannesburg \\ ${ }^{2}$ Departement Mineralogie, Technische Universität Bergakademie Freiberg \\ *bertuss@uj.ac.za
}

\section{Inleiding}

Die Witwatersrand-Mozaanopeenvolging van Suider-Afrika is tussen $\sim 3.0$ en $\sim 2.8$ biljoen jaar gelede op 'n oerkontinent bekend as die Kaapvaalkraton afgeset. Hierdie opeenvolging is dus een van die oudste en bes bewaarde suprakratoniese opeenvolgings op aarde. ${ }^{1}$

Daar bestaan 'n sterk litostratigrafiese korrelasie tussen die Mozaangroep van die Pongolasupergroep en die Wesrand- en Sentraalrandgroep van die Witwatersrandsupergroep. . $^{1,2,3}$ 
Die implikasie hiervan is dat die Mozaangroep en Witwatersrandsupergroep oorspronklik deel van dieselfde sedimentêre kom gevorm het. Hierdie korrelasie kan versterk word en afsettingstoestande in die oeroseaan kan bestudeer word deur middel van 20 kenmerkende ysterryke sedimentêre lae in die Witwatersrand-Mozaanopeenvolging. ${ }^{3,4}$ Hierdie ysterryke sedimentêre lae bestaan uit ysterformasies en ysterryke modderstene. Ysterformasies is tjerthoudende chemiese sedimentêre gesteentes met 'n abnormale hoë ysterinhoud wat in sekere gevalle sterk geband is. Ysterryke modderstene daarenteen bestaan uit ysterryke minerale in 'n modderige grondmassa van aluminiumryke silikate.

Hierdie bydrae fokus op die korrelasie tussen die ysterformasies van Kronkellaag (Wesrandgroep) en Scotts Hill (Mozaangroep) en die ysterryke modderstene van Rietkuil (Wesrandgroep) en Nconga (Mozaangroep).

\section{Die Kronkellaag- en Scotts Hill-ysterformasies}

Die Kronkellaag-ysterformasie kom voor in die boonste deel van die Parktownformasie, en die Scotts Hill-ysterformasie kom in die boonste deel van die Ntombeformasie van onderskeidelik die Wesrand- en Mozaangroep voor. Die eenhede vergelyk goed ten opsigte van litostratigrafie en geochemie, maar verskil ten opsigte van dikte, mineralogie, metamorfose en $\ddot{a}^{13} \mathrm{C}_{\mathrm{PDB}}{ }^{-}$ karbonaatwaardes. Die dikteverskille kan verklaar word aan die hand van variasies in die morfologie van die afsettingskom. Daarteenoor word die mineralogiese samestelling en graad van metamorfose beïnvloed deur die aanwesigheid van diabaasplate wat die Scotts Hillysterformasie plaaslik binnedring. Die verskil in $\ddot{a}^{13} \mathrm{C}_{\mathrm{PDB}}-$ karbonaatwaardes dui daarop dat daar moontlik 'n groter toevoer van organiese koolstof aan die Scotts Hill was, en dat dit in vlakker water afgeset is as die Kronkellaag. Hierdie interpretasie word gesteun deur 'n oksiedfasiese ysterformasie aan die onderkant van die Kronkellaag, wat op afsetting in dieper water as die Scotts Hill dui. ${ }^{5}$

\section{Die Rietkuil- en Ncongaformasies}

Korreleerbare ysterryke modderstene kom in die middel van die Rietkuil- en Ncongaformasies van onderskeidelik die Wesrand- en Mozaangroep voor. In laasgenoemde geval is daar ook 'n dun ysterformasie aanwesig. Die twee ysterryke modderstene vergelyk goed op grond van hulle litostratigrafiese plasing. Hulle verskil egter ten opsigte van mineralogiese en chemiese samestelling. Die aluminiuminhoud van die Rietkuil- ysterryke moddersteen is hoër as dié in die Nconga, wat op hoër klastiese invoer in die Rietkuilomgewing van die afsettingskom dui.

\section{Implikasies en gevolgtrekking}

Die laterale aaneenlopendheid van die Kronkellaag- en Scott Hill-ysterformasies dui op komwye afsluiting van klastiese toevoer tydens hul afsetting. Dit beteken dat die Kaapvaalkraton op daardie tydstip totaal verdronke was deur 'n oseaan waarvan die diep water verryk is in terme van 'n ysterryke hidrotermale komponent. Daarteenoor het die kraton nog steeds heelwat klastiese invoer beleef gedurende die afsetting van die Rietkuil- en Nconga- ysterryke modderstene. Die Nconga was wel verder verwyder van die klastiese bron. Die ysterformasie in die Nconga kan moontlik op 'n paleohoog, beskerm van klastiese invoer, afgeset wees.

Suid-Afrikaanse Tydskrif vir Natuurwetenskap en Tegnologie, Jaargang 29 No. 3: September 2010 


\title{
Verwysings
}

1. Beukes, N.J.\& Cairncross, B. (1991). A lithostratigraphic-sedimentologicals reference profile for the Late Archaean Mozaan Group, Pongola Sequence: application to sequence stratigraphy and correlation with the Witwatersrand Supergroup, Suid-Afrikaanse Joernaal vir Geologie, 94(1):44-69.

2. Nelson, J.P., Beukes, N.J.\& Cairncross, B. (1995). Tectono-stratigraphic setting of the $\sim 2.9$ Ga Mozaan Group of the Pongola Supergroup and correlation with the Witwatersrand Supergroup, Uitgebreide Opsommings van die Suid-Afrikaanse Geokongres, Geologiese Vereniging van Suid-Afrika, 838840.

3. Nhleko, N. (2003). The Pongola Supergroup in Swaziland. Ongepubliseerde PhD tesis. Departement Geologie, Rand Afrikaanse Universiteit, 300.

4. Beukes, N.J. (1995). Stratigraphy and Basin Analyses of the West Rand Group with Special Reference to Prospective Areas for Placer Gold Deposits, Ongepubliseerde verslag, Departement Geologie, Rand Afrikaanse Universiteit.

5. Beukes, N.J. (2004). Early options in photosynthesis, Nature, 431:522-523.

\section{Lithostratigraphic correlation of the iron-rich sedimentary rocks of the Witwatersrand- Mozaan Succession: implications for early depositional environments on earth}

The Witwatersrand Supergroup and the Mozaan Group of the Pongola Supergroup were likely deposited in the same sedimentary basin at $\sim 2.9 \mathrm{Ga}$. A study of correlateable iron-rich units in these groups helps to define the paleo-oceanographic conditions in the Archean.

\section{Die afskaling van globale sirkulasiemodelvoorspellings na daaglikse reënval oor die Bo-Olifantsrivieropvanggebied}

\author{
*S. STEYn \& S. WALKer \\ Departement van Grond-, Gewas- en Klimaatwetenskappe, Universiteit van die Vrystaat \\ *steynas.sci@ufs.ac.za
}

Klimaatverandering kan verreikende gevolge vir al die vlakke van die samelewing inhou. Die volgehoue vrylating van kweekhuisgasse (KHG) teen die huidige of 'n hoër tempo sal verdere wêreldverwarming teweegbring en verdere veranderinge in die globale klimaatstelsel veroorsaak. Dit geld veral vir Suider-Afrika, waar 'n steeds groeiende bevolking reeds 'n toename in die vraag na vars water veroorsaak, en waar die landbou en voedselproduksie grotendeels van reënval afhanklik is.

Globale sirkulasiemodelle (GSM'e) is die hoofbron van klimaatvooruitskouings ten opsigte van veranderende KHG-vrystellingscenario's. Die ruimtelike resolusie van GSM'e is te grof om prosesse soos konveksie en reënval wat kleiner as die roosterveld is, te hanteer. Landbouhidrologiese toepassingsmodelle vereis dikwels inligting by 'n netwerk punte, wat die afskaal van die GSM-uitvoer noodsaak. Afskalingsbenaderings het gevolglik ontluik as 'n middel om grootskaalse atmosferiese voorspellersvelde (soos die $500 \mathrm{hPa}$-meridionale windspoed) in te span om stasievlak weerkundige reekse te ontwikkel. Veranderlikes soos die daaglikse reënval, wat nie altyd akkuraat deur GSM'e voorgestel word nie, kan afgelei word deur middel van statistiese metodes wat verwantskappe vaslê tussen die vereiste parameters en veranderlikes wat meer akkuraat gesimuleer word.

In die verlede het navorsers die statistiese afskalingsmodel (SDSM) ingespan om klimaatprojeksies van daaglikse reënval oor Noord-Amerika en Europa af te skaal. 'n Soortgelyke 
metodologie is aangeneem om daaglikse reënvalprojeksies by vyf gekose subopvanggebiede in die Bo-Olifantsrivier af te skaal. Die afskaling is vir die somermaande Desember, Januarie en Februarie uitgevoer (DJF).

Die stel generiese voorspellers, wat oor al vyf subopvanggebiede geïdentifiseer is, sluit oppervlakwindsterkte, vortisiteit, divergensie en spesifieke humiditeit, $850 \mathrm{hPa}$-windrigting en relatiewe humiditeit asook $500 \mathrm{hPa}$-relatiewe humiditeit en meridionale windspoed in. In die algemeen het al die voorspellers relatief lae verklarende vermoëns getoon. Die aansienlike variasie in die gevolglike korrelasies tussen die grootskaalse voorspellers en die waargenome daaglikse reënval by die gekose subopvanggebiede kan moontlik toegeskryf word aan die konvektiewe aard van die reënvalpatrone, wat onreëlmatig in tyd en ruimte versprei is. In die algemeen was resultate wat met behulp van die afskalingsmodel behaal is, nie baie bemoedigend nie, aangesien dit nie daarin geslaag het om aanvaarbare resultate vir vier uit die vyf subopvanggebiede te verskaf nie.

Vir een van die subopvanggebiede, naamlik Groblersdal, is die vooruitgeprojekteerde veranderinge vir toekomstige klimaat aan die hand van 'n aantal deltastatistieke geëvalueer. Slegs 'n paar van die indekse het 'n duidelike verandering getoon, terwyl die meeste indekse vir DJF inkonsekwent veranderings oor drie toekomstige periodes wat op die 2020's, 2050's en 2080's fokus, getoon het. Daar moet daarop gelet word dat die geprojekteerde veranderinge dikwels kleiner as die modelfoute is, wat impliseer dat die afskalingsmodel eenvoudig nie sensitief genoeg is om die blindelingse aanvaarding van die geprojekteerde veranderinge moontlik te maak nie. Die resultate moet gevolglik omsigtig gebruik word. Die feit dat die afskalingsprosedure soortgelyke resultate ten opsigte van verskillende KHG-vrystellingscenario's lewer, toon dat dit ten minste rigied en stabiel is.

\title{
Downscaling of global circulation model projections to daily rainfall over the Upper Olifants River Catchment
}

The statistical downscaling model (SDSM) was used to downscale climate projections of daily rainfall at five quaternary catchments within the Upper Olifants River catchment for the summer months. The downscaling model results were not very encouraging as the model failed to produce satisfactory results for four of the five quaternary catchments.

\section{'n Evalueringsinstrument vir wetenskaphandboeke vir UGO in Suid-Afrika}

\author{
S. SWANEPoel \\ Departement Verdere Onderwysersopleiding, Unisa \\ sarita@swanepoel.net
}

Ons leef in 'n tyd waarin die wetenskap vinnig ontwikkel en geïmplementeer word. Goeie wetenskaponderrig is nodig om leerders vir die lewe in so 'n wêreld voor te berei. Onlangse studies het getoon dat baie wetenskaponderwysers in Suid-Afrika onvoldoende opleiding en ervaring het, veral in die konteks van uitkomsgebaseerde onderwys. Vir hierdie onderwysers en hul leerders kan goeie handboeke van onskatbare waarde wees. Hierdie studie fokus op die evaluering van handboeke vir wetenskaponderrig.

Suid-Afrikaanse Tydskrif vir Natuurwetenskap en Tegnologie, Jaargang 29 No. 3: September 2010 
Die kwaliteit van handboeke word geëvalueer op grond van die mate waarin leerders wetenskap bemeester wanneer hulle die handboeke gebruik. Ideaal gesproke behoort handboeke dus in gekontroleerde omstandighede gebruik te word om die impak daarvan op die leerders te bepaal. Ongelukkig is dit dikwels onmoontlik om handboeke voor gebruik so te toets.

'n Ander benadering sou wees om die kwaliteit van 'n handboek te beoordeel na aanleiding van die teenwoordigheid van 'n bepaalde versameling eienskappe wat sowel onderrig as leer steun. Handboeke kan dus geëvalueer word deur die teenwoordigheid van hierdie eienskappe te ondersoek. Hierdie eienskappe dra egter nie ewe veel tot die kwaliteit van die handboek by nie, dus moet gewigte daaraan toegeken word.

'n Geskikte handboekevalueringsinstrument wat genoemde eienskappe, die gewigte wat daaraan toegeskryf word, die evalueringsprosedure en die puntetoekenning omskryf, kan betroubare en regverdigbare evalueringsresultate verseker. Daar bestaan tans nie so 'n evalueringsinstrument vir wetenskaponderrighandboeke in die konteks van uitkomsgebaseerde onderwys in die VOO-fase in Suid-Afrika nie. In hierdie navorsing word daar gepoog om met behulp van die analities hiërargiese proses (AHP) so 'n evalueringsinstrument te ontwikkel en die geldigheid en betroubaarheid van evalueringsresultate wat daarmee behaal word, te toets.

Die eienskappe wat die kwaliteit van 'n handboek beïnvloed, is geïdentifiseer uit die literatuur en na aanleiding van bestaande evalueringsinstrumente en die behoeftes van groepe wat belang het by wetenskaponderrig in Suid-Afrika. In ooreenstemming met die AHP is die eienskappe in kategorieë verdeel om 'n hiërargie of boomstruktuur te verkry. Daar is onderhoude gevoer met twee vakkenners, wat die inhoudsgeldigheid van die geïdentifiseerde eienskappe bevestig het. Vervolgens het tien onderwysers wat kenners op hul vakgebiede is, elke eienskap vergelyk met elke ander eienskap op dieselfde vlak. Die resultate van hierdie paarsgewyse vergelykings is met behulp van die Expert Choice-rekenaarprogram verwerk om die gewigte te bereken.

'n Rubriek is geformuleer om vir elke eienskap te beskryf hoe 'n punt uit drie toegeken kan word deur te beskryf presies watter aanwysers in die handboek moet voorkom. Onderwysers wat ' $n$ handboek evalueer, merk op die rubriek watter aanwysers teenwoordig is. Die punt uit drie word dan op ' $n$ sigbladprogram ingelees en saam met die gewigte verwerk om te bepaal in watter mate die handboek elke individuele eienskap en elke kategorie vertoon en laastens ook wat die kwaliteit van die handboek in sy geheel is (as persentasies).

Die instrument is op klein skaal aangewend en verstel. Daarna is dit op groter skaal aangewend en is die resultate se betroubaarheid getoets. Goeie ooreenstemming tussen die resultate wat verkry is en die opinies van ervare onderwysers wat die handboeke sonder die instrument geëvalueer het, het die geldigheid daarvan bevestig.

\section{An evaluation instrument for science textbooks for OBE in South Africa}

Textbooks of good quality can assist teachers and learners of science. Currently, no evaluation instrument exists that is appropriate for the evaluation of science textbooks in the context of OBE in South Africa. This study aims to utilise the Analytic Hierarchy Process to develop and test an appropriate instrument. 


\title{
RF-bestraling van kalsiet/dolomiet-monsters
}

\author{
*A.J. Swart, C. Pienaar \& P. Mendonidis \\ Fakulteit van Ingenieurswese en Tegnologie, Vaal-Universiteit van Tegnologie \\ *jamess@vut.ac.za
}

\section{Inleiding}

Eienskappe soos die impedansie en resonansiepunte van spesifieke rotsmonsters kan deur middel van radiofrekwensie- (RF-) toerusting en innoverende koppelingstegnieke bepaal word. In 2007 is hierdie metingsmetode en -resultate in ' $n$ referaat by die studentesimposium van die SAAWK bespreek. Sedertdien is die metode deur middel van 'n alternatiewe meetinstrument en deur middel van RF-bestralingstoetse op spesifieke rotsmonsters bevestig. Hierdie voordrag toon die resultate van die tweede metode waarvolgens die resonansiepunte van rotse bepaal kan word. Die gevolge van die oordrag van RF-energie aan 'n diëlektriese materiaal ('n kalsiet/ dolomietrotsmonster) deur middel van 'n selfontwerpte aanpassingstroombaan word ook in die voordrag aangetoon.

'n Vektorvoltmeter en 'n netwerkanaliseerder is gebruik om die resonansiepunte van 'n diëlektriese materiaal binne 'n parallelplaatkapasitor te meet. Die vektorvoltmeter dui 'n resonansiepunt vir ' $\mathrm{n}$ kalsiet/dolomiet-rotsmonster (afmetings $30 \times 19 \times 4 \mathrm{~mm}$ ) by 'n frekwensie van $160 \mathrm{MHz}$ aan. Die resonansiepunt, wat deur middel van 'n netwerkanaliseerder bevestig is, is vervolgens gebruik om 'n aanpassingstroombaan te ontwerp om die maksimum RF-energie deur middel van 'n hoëdrywing-RF-versterker aan die rotsmonsters oor te dra.

\section{Die parallelplaatkapasitor met sy aanpassingstroombaan}

Die rotsmonster word tussen twee koperplate in 'n houtklembeuel vasgeklem om 'n parallelplaatkapasitor te vorm. Koaksiale kabels is gebruik om die koperplate met behulp van 'n N-tipe kabelskoen aan die meettoerusting te koppel. Elektriese resonansie word aangedui by 'n frekwensie waarby die impedansie 'n suiwer weerstand is (fasehoek $=0^{\circ}$ ).

Die impedansie van die rotsmonster is nagenoeg $1.5 \Omega$, terwyl die RF-versterker 'n uitsetimpedansie van $50 \Omega$ het. Gevolglik kan die twee nie direk aan mekaar gekoppel word nie, omdat die meeste van die RF-energie na die versterker teruggekaats sal word. 'n Aanpassingstroombaan bestaande uit ' $n \pi$-tipe netwerk van kapasitors en induktors is ontwerp om die $1.5 \Omega$ aan te pas by die $50 \Omega$ vir die resonansiepunt. Die aanpassingsnetwerk is met behulp van die netwerkanaliseerder ingestel om die laagste moontlike staandegolfverhouding (SGV) te verseker.

\section{Waarnemings en gevolgtrekkings}

Die SGV (2.02) van die opstelling is bepaal deur middel van 'n RF-reflektometer wat die toevoer en weerkaatste drywing aandui. 'n Kommersiële RF-sender plus 'n RF-versterker is gebruik om drywing van ongeveer $100 \mathrm{~W}$ aan die rotsmonster te lewer. 'n Infrarooi digitale termometer is gebruik om die opervlaktemperatuur (sowat $140^{\circ} \mathrm{C}$ ) van die monster na vier minute se RFbestraling te meet. 'n Aansienlike kleurverandering van die monster se oppervlak (van 'n ligte na 'n donkerroom kleur) is waargeneem.

Die resultate van die toetse kan nou aangewend word om die gebruik van RF-energie in rotsvergruising en minerale veredelings na te vors. 'n Aansienlike besparing in die verbruik van

Suid-Afrikaanse Tydskrif vir Natuurwetenskap en Tegnologie, Jaargang 29 No. 3: September 2010 
elektriese energie deur groot industriële myntoerusting word voorspel, sowel as 'n verhoging in die persentasie kosbare minerale wat herwin kan word.

\title{
RF radiation of calcite/dolomite samples
}

Calcite/dolomite samples, within a parallel-plate capacitor, are radiated by a RF amplifier at a resonating frequency of $160 \mathrm{MHz}$. The surface temperature of these samples increased to $140^{\circ} \mathrm{C}$ after four minutes of RF radiation. The measuring techniques used to determine the resonating frequency and maximum power transfer are presented.

\section{Die evaluering van goud(I)-P,N- heteroditopiese verbindings as antivirale agente}

\author{
T. Traut ${ }^{A, B}$, R. Hewer ${ }^{\wedge}$, J. Coates ${ }^{A}$, W.E. van $Z_{Y L}{ }^{\text {B,C }}$ \& D.B.G. Williams ${ }^{\text {B* }}$ \\ ${ }^{a}$ AuTEK Biomed, Advanced Materials Division, Mintek, Randburg \\ bepartement Chemie, Universiteit van Johannesburg \\ 'Departement Chemie, Universiteit van KwaZulu-Natal \\ *bwilliams@uj.ac.za
}

Die gebruik van heteroditopiese P,N-ligande in die farmaseutiese industrie is goed gedokumenteer in die literatuur. ${ }^{1,2}$ Hierdie gebruike behels meestal die metaalkomplekse van die P,N-ligande, ${ }^{3}$ aangesien die verskil in metaalbindingsaffiniteit tussen fosfor- en stikstofatome die onderliggende rede vir die sukses van hierdie klas verbindings is. ${ }^{4}$ Vele voorbeelde met palladium, rodium en iridium as kompliseringsmetaal is alreeds in die literatuur bekend, maar daar is verbasend min voorbeelde van die goudkompleksering van hierdie ligande. Hierdie leemte in die literatuur het aanleiding gegee tot die voorbereiding van 'n diverse reeks $\mathrm{P}, \mathrm{N}$-ligande vir goud(I)-kompleksering. ${ }^{5}$ Die doel met hierdie opvolgprojek was om die antivirale aktiwiteit van die voorbereide komplekse in 'n verskeidenheid biologiese toetse te evalueer.

Inleidende in vitro- biologiese toetse het een $\mathrm{P}, \mathrm{N}$-ligand en vyf goud(I)-komplekse met belowende antivirale aktiwiteit en aanvaarbare biologiese identiteite geïdentifiseer. Die verdere diepte-evaluering van hierdie ses verbindings het onder andere teoretiese berekenings van die "geneesmiddelagtigheid" (druglikeness) en 'n analise van enige inherente potensiaal vir negatiewe effekte ingesluit. Al ses verbindings het goed met verwysingsverbindings (AZT en Auranofin) vergelyk. Die sitotoksisiteit van elke verbinding is in twee sellyne (PBMC en PM1) bepaal, terwyl die antivirale aktiwiteit deur middel van fluoressensie-analise in ko-kulture van Magi-CCR5 en latent geïnfekteerde MT-4-sellyne bepaal is. Die wateroplosbaarheid, lipofiliese potensiaal en opname van elke verbinding in gesonde menslike limfosiete (PBMC- en CEMss-sellyne) is ondersoek, aangesien hierdie faktore 'n baie belangrike rol in die biobeskikbaarheid van orale medisinale agente speel. Daar is bevind dat elk van die toetsverbindings goeie oplosbaarheid en lipofiliese identiteit in die biologiese omgewing toon, en dat opname in menslike limfosiete op 'n konsentrasie-afhanklike wyse plaasvind - 'n aanduiding van passiewe diffusie deur die selmembraan. Voorts kon verskeie biologiese interverwantskappe vir die P,N-goud(I)-komplekse ten opsigte van opname, oplosbaarheid en die gepaardgaande sitotoksisiteit waargeneem word.

Om op te som: 'n reeks P,N-goud(I)-komplekse is in 'n verskeidenheid in vitro-biologiese toetse gesintetiseer, gekarakteriseer en getoets. Ses van die toetsverbindings het goeie biologiese 
identiteite getoon en geblyk belowende kandidate vir die verdere ontwikkeling van potensiële antivirale agente te wees.

\title{
Bedankings
}

Die outeurs bedank graag AuTEK Biomed (Mintek en Harmony Gold) vir toestemming om hierdie resultate te publiseer, asook vir hul finansiële ondersteuning.

\section{Verwysings}

1. Ghilardi, C. A., Midollini, S., Moneti, S., Orlandini, A. \& Scapacci, G. (1992). J. Chem. Soc. Dalton Trans., 3371-3376.

2. Chen, X., Femia, F. J., Babich, J. W. \& Zubieta, J. (2001). Inorg. Chim. Acta, 315:147-152.

3. Raduloviæ, V., Bacchi, A., Pelizza, G., Sladiæ, D., Bræeski, I. \& Andjelkoviæ, K. (2006). Monatshefte für Chemie, 137:681-691.

4. Knebel, W. J., Angelici, R. J. \& Inorg. Chem., 1974, 13:627.

5. Williams, D.B.G., Traut, T., Kriel, F.H. \& van Zyl, W.E. (2007). Inorg. Chem. Comm., 10:538-542.

\section{Evaluation of gold(I) $P, N$ heteroditopic complexes as antiviral agents}

A range of $\mathrm{P}, \mathrm{N}$ gold(I) complexes was synthesised, characterised and screened through a variety of in vitro biological assays. All compounds exhibited acceptable biological profiles and several proved to be promising candidates for the development of potential antiretroviral agents.

\section{Die ontwikkeling van ' $n$ in vitro-eritrosiet-oksidasieskadetoets vir die bepaling van die anti-oksidantaktiwiteit van plant- en heuningekstrakte}

\author{
C.P. UYs ${ }^{1}$ \& M. BESTER ${ }^{2}$ \\ Departement Anatomie, Universiteit van Pretoria \\ 1neliauys@gmail.com \\ ${ }^{2}$ megan.bester@up.ac.za
}

Lipiedperoksidasie lei daartoe dat vry radikale 'n kettingoksidasiereaksie van membraan polionversadigde vetsure veroorsaak. Hierdie kettingreaksie verswak die struktuur en beskermende funksie van selmembrane. Byprodukte van oksidasieprosesse is lipiedhidroperoksiede en sekondêre byprodukte soos malondialdehied (MDA). Hierdie byprodukte bind eritrosietfosfolipiede en proteïne en veroorsaak veranderings in die struktuur van die membraandubbellaag. Dit het ook 'n negatiewe uitwerking op die werking van membraangebonde proteïne. MDA, 'n bekende byproduk van die lipiedperoksidasie van eritrosiete, bind eritrosietfosfolipiede en proteïne en inhibeer 'n verskeidenheid membraanverwante funksies. Dit het ook 'n negatiewe uitwerking op die oorlewing van eritrosiet.

Die in vitro-eritrosiet-oksidasieskadetoets gebruik reaktiewe suurstofspesies om vas te stel of 'n dwelm, plantekstrak of enige ander natuurlike produkte soos heuning antioksidantaktiwiteit toon. 2,20-asobis- (2-amidinopropaan-) dihidrochloried (AAPH) kan gebruik word om hierdie reaktiewe suurstofspesies te vorm. Wanneer AAPH termolise ondergaan, vorm dit stikstof en 2 alkielradikale wat met suurstofvormende peroksielradikale reageer. Die radikale wat as gevolg 
van hierdie reaksie vorm, veroorsaak oksidasiespanning in baie weefsel- en seltipes, insluitende eritrosiete. Eritrosiete is weens die hoë inhoud aan poli-onversadigde vetsuur in hul membrane en hoë sellulêre suurstof- en hemoglobien-(Hb-)konsentrasies uiters sensitief vir oksidasiespanning. Eritrosietmembraanskade as gevolg van oksidasiespanning veroorsaak dat die selinhoud uit die sel uit beweeg, veral $\mathrm{Hb}$. As gevolg van $\mathrm{Hb}$ se hoë en spesifieke absorbansie by $570 \mathrm{~nm}$ kan die meting van Hb-vlakke gebruik word om die oksidasieskade wat die sel ondergaan het, te meet.

Die hoofdoel met hierdie studie was om die in vitro-eritrosiet-oksidasieskadetoets op te stel en met behulp van Trolox ('n bekende anti-oksidant) te bewys dat dit werk. Die antioksidantaktiwiteit van twee plantekstrakte (kool en pampoen) en twee heuningmonsters (donker fynbos- en lietsjieheuning) is bepaal en die uitwerking van die in vitro-eritrosiet-oksidasieskadetoets op eritrosietmorfologie is deur middel van skanderingselektronmikroskopie vasgestel.

Daar is bevind dat Trolox, pampoenekstrak, donker fynbosheuning en lietsjieheuning die eritrosietmembrane beskerm het teen oksidasieskade as gevolg van AAPH. Koolekstrak het die eritorisietmembrane egter nie genoegsaam beskerm nie. Skanderingselektronmikroskopie het ook bewys dat Trolox nie morfologiese eritrosietmembraanskade veroorsaak het nie, maar dat dit anti-oksiderende aktiwiteit toon soos reeds aangetoon deur middel van die toets.

Die gevolgtrekking wat op grond van hierdie studie gemaak is, is dat die in vitroeritrosietoksidasieskadetoets gebruik kan word om te bepaal of 'n produk antioksidantaktiwiteit toon en of membraanskade plaasgevind het. Alhoewel die ekstrakte wat in hierdie studie getoets is nie eritrosietmembraanskade veroorsaak het nie, het die Trolox, pampoenekstrak, donker fynbosheuning en lietsjieheuning die eritrosietmembrane beskerm teen skade as gevolg van AAPH. Hierdie produkte is dus antioksidante. Alhoewel koolekstrak op sigself nie die eritrosietmembrane beskadig het nie, het dit ook nie 'n duidelik beskermende rol gespeel teen oksidasieskade as gevolg van AAPH nie.

\title{
The establishment of the in vitro erythrocyte antioxidant assay for the determination of the antioxidant activity of plant and honey extracts
}

The in vitro erythrocyte damage assay indicated that in contrast to cabbage, Trolox, pumpkin, dark fynbos honey and litchi honey do have antioxidant-activity. Scanning electron microscopy indicated that Trolox does not cause morphological alterations to the erythrocyte membranes but does have antioxidant activity as indicated by the assay.

\section{Ontwikkeling van 'n opto-elektroniese stelsel vir die karakterisering van ultravioletsensitiewe fotodiodes}

\author{
*L. van Schalkwyk, M. Diale, W.E. Meyer \& F.D. Auret \\ Departement Fisika, Universiteit van Pretoria \\ *Louwrens.vanschalkwyk@up.ac.za
}

'n Ultraviolet- (UV-) ligbron en monochromator is by 'n bestaande stroomspanning-(IV-) karakteriseringstasie gevoeg vir die karakterisering van verskeie fotodiodes. Die opto-elektroniese stelsel is toegerus met 'n deuteriumligbron wat uitstraal in 'n golflengtegebied van $190 \mathrm{~nm}$ tot 400 nm, 'n Czerny-Turner-tipe monochromator en 'n solarisasiebestande optiese vesel om die 
lig na die fotodiode te lei. Die opto-elektroniese stelsel is verder toegerus met 'n HP4140B-pAmeter/DC-bron vir die verskaffing van voorspannings en die meet van stroom. Hierdie opstelling kan die responsie van fotodiodes by verskillende golflengtes met of sonder voorspanning ondersoek. Verder maak die gebruik van 'n monochromator dit moontlik om IV-metings te doen terwyl die fotodiode met 'n spesifieke golflengte lig belig word. 'n LabVIEW-program help met die beheer van die stelsel en die opname van metings. Responsie word in fotostroomdigthede as 'n funksie van golflengtes bepaal. Vanuit die IV-metings word die idealiteitsfaktor, walhoogte, serieweerstand, versadigingstroom en lekstroom van die fotodiodes verkry. Die stelsel is gebruik om die responsie en IV-karakteristieke van laboratorium-AlGaN-fotodiodes te ondersoek en met kommersiële AlGaN-fotodiodes te vergelyk. Die laboratorium-AlGaN-fotodiodes word in die Fisikadepartement voorberei en bestaan uit 'n Schottky-kontak op ' $\mathrm{n} \mathrm{Al}_{0.55} \mathrm{Ga}_{0.45} \mathrm{~N}$-halfgeleier. Daar is bevind dat die laboratoriumfotodiode 'n beter idealiteitsfaktor (1.3 teenoor 1.5), 'n laer walhoogte $(1.1 \mathrm{~V}$ teenoor $1.2 \mathrm{~V})$, 'n laer serieweerstand $\left(0.31 \Omega \mathrm{cm}^{2}\right.$ teenoor $\left.310 \Omega \mathrm{cm}^{2}\right)$, 'n byna gelyke versadigingstroom $\left(110 \mathrm{fA} / \mathrm{cm}^{2}\right.$ teenoor $\left.120 \mathrm{fA} / \mathrm{cm}^{2}\right)$ en 'n kleiner lekstroom by 1 V-truspanning $\left(23 \mathrm{pA} / \mathrm{cm}^{2}\right.$ teenoor $\left.38 \mathrm{nA} / \mathrm{cm}^{2}\right)$ as die kommersiële fotodiode het. Die laboratoriumfotodiode het 'n piekresponsie by $271 \mathrm{~nm}(4.6 \mathrm{eV})$ met 'n fotostroomdigtheid van $10 \mathrm{nA} / \mathrm{cm}^{2}$ getoon. Dit is naby aan die piekresponsie van die kommersiële fotodiode by $266 \mathrm{~nm}$ $(4.7 \mathrm{eV})$, maar die fotostroomdigtheid van die laboratorium is veel minder as die $140 \mathrm{nA} / \mathrm{cm}^{2}$ van die kommersiële fotodiode.

\title{
Development of an optoelectronic system for the characterisation of ultraviolet-sensitive photodiodes
}

An existing current-voltage (IV) characterisation system was equipped with a deuterium light source and monochromator, allowing the measurement of the wavelength dependence of the response of photodiodes at different wavelengths. IV measurements can also be done while the photodiode is illuminated with light of a specific wavelength. Furthermore, the ideality factor, barrier height, series resistance and saturation current are also determined. We present response curves in terms of photocurrent densities and IV measurements mainly for ultraviolet lightsensitivity comparisons between laboratory prepared and commercially available AlGaN photodiodes.

\section{'n Gestaltegespreksagent met outistiese gedrag}

\author{
W. VENTER \\ Departement Rekenaarwetenskap, Universiteit van Stellenbosch \\ wventer@cs.sun.ac.za
}

Oor die afgelope paar jaar is heelwat navorsing oor gestaltegespreksagente gedoen. Die doel was om virtuele agente te skep wat geloofwaardig ten opsigte van gedrag, spraak en interaksie met die gebruiker sou wees. Die persoonlikhede van die agente is aan die hand van geparametriseerde emosies en karaktereienskappe gedefinieer.

Ons beoog om op vorige werk wat in die veld verrig is, voort te bou en 'n nie-neurotipiese agent te programmeer. Ons wil spesifiek 'n agent skep wat die tipiese gedragstrekke van 'n persoon met Asperger se Sindroom openbaar. Met hierdie doel voor oë stel ons 'n stelsel voor wat eerder op konkrete reëls as op ware skynintelligensie berus. Die rede hiervoor is dat mense

Suid-Afrikaanse Tydskrif vir Natuurwetenskap en Tegnologie, Jaargang 29 No. 3: September 2010 
geneig is tot antropomorfisme. In die verlede het betreklik eenvoudige stelsels mense al by 'n "gesprek" betrek, selfs al het hulle besef dat hulle besig was om met 'n "dom" rekenaarprogram te kommunikeer.

Die stelsel bestaan uit drie kernkomponente: een wat persoonlikheid definieer en emosies beheer, een wat insette en toevoer beredeneer, en een wat die agent se wêreldkennis stoor. Rondom hierdie kernkomponente is daar 'n koppelvlak wat toe- en afvoer beheer.

Om ons agent aan 'n gebruiker voor te hou, ontwikkel ons 'n klein virtuele omgewing. Hierdie omgewing word gebou op 'n aparte stelsel wat deur 'n kollega aan die Universiteit van Stellenbosch ontwikkel is met die doel om as basis vir terapieprogramme te dien. Indien die tyd dit toelaat, beoog ons ook om ons stelsel op die gewilde virtuele Internet-gemeenskap Second Life te laai. Weens tydsbeperkinge sal hierdie aanvanklike agent egter redelik eenvoudig wees wat sy wêreldkennis en redenasievermoë betref.

Nadat die stelsel ontwikkel is, beoog ons om 'n hoëvlakraamwerk te skryf wat die definisie van 'n spesifieke persoonlikheid sal vergemaklik. Só 'n raamwerk sal die proses waartydens die agent se emosies, gedragstrekke, kennisgebied, interaksie-reëls en terugvoer gedefinieer word, vereenvoudig.

Een moontlike toepassing van só 'n agent sal in die onderwys wees: 'n rekenaarprogram wat sosiale vaardighede ontwikkel, sal 'n agent as metgesel van die leerder kan implementeer. Namate die program deurgewerk word, sal die agent se sosiale vaardighede kan ontwikkel ten einde die leerder te help en aan te moedig. 'n Ander moontlike toepassing sou wees om die agent aan 'n neurotipiese persoon voor te hou. In hierdie geval sal die neurotipiese persoon meer oor outisme te wete kon kom.

\section{An embodied conversational agent with autistic behaviour}

Our goal is to create an embodied conversational agent (ECA) which exhibits non-neurotypical behaviour; specifically a child who has Aspergers Syndrome. To this end, we are building a framework to define ECA personalities and knowledge domains. 